\title{
Faulty Assumptions and Undemocratic Consequences of Campaign Finance Reform
}

\author{
Bradley A. Smith ${ }^{\dagger}$
}

Very few aspects of American politics fit the metaphor of Plato's cave better than the realities of American campaign finance. ${ }^{1}$

\section{INTRODUCTION}

Over the past twenty-five years, efforts to reform the campaign finance system have been exceptionally popular with both the general public ${ }^{2}$ and legal academics, ${ }^{3}$ and few commentators have argued against the need for some kind of reform. Most reformers have attempted to limit alleged political "corruption" and to promote a brand of political equality. Taking an instrumentalist view of the First Amendment, they have chafed at the more libertarian First Amendment approach to campaign finance taken by the Supreme Court in Buckley v. Valeo. ${ }^{4}$

This Essay argues that reform scholarship has erred in its assumptions about the causes and effects of political corruption. It challenges the basic

$\dagger$ Assistant Professor, Capital University Law School.

1. Frank J. Sorauf, Inside Campaign FinANCE 26 (1992).

2. For examples of reform advocacy outside legal circles, see ElIZABETH DREW, POLITICS AND Money: The New Road to Corruption (1983); Philip M. Stern, The Best Congress Money Can BUY (1988). Over 400 newspapers editorialized in favor of campaign finance reform in 1988. HERBERT E. AlEXANDER \& MONICA BAUER, FINANCING THE 1988 Election 113 (1991). In the 1994 elections, Missouri, Montana, and Oregon passed referenda limiting contributions in support of state legislative candidates to just $\$ 100$. A similar measure passed in Washington, D.C., in 1992. See Alversie Mitchell \& Doug Funderburk, We Must Finish Campaign Finance Overhaul, KANSAS CiTY STAR, Apr. 14, 1995, at C7. However, voters in Colorado defeated a similar proposal. See id.

3. See, e.g., Daniel H. Lowenstein, On Campaign Finance Reform: The Root of All Evil Is Deeply Rooted, 18 Hofstra L. REv. 301, 348-60 (1989); Marlene A. Nicholson, Continuing the Dialogue on Campaign Finance Reform: A Response to Roy Schotland, 21 CAP. U. L. REV, 463, 471-82 (1992); Fred Wertheimer \& Randy Huwa, Campaign Finance Reforms: Past Accomplishments, Future Challenges, 10 N.Y.U. REv. L. \& SoC. CHANGE 43 (1980-81); Fred Wertheimer \& Susan W. Manes, Campaign Finance Reform: A Key to Restoring the Health of Our Democracy, 94 COLUM. L. REV. 1126, 1149-57 (1994). This is but the tip of an enormous iceberg of legal literature urging restrictions on campaign spending, contributions, or both.

4. 424 U.S. 1 (1976) (per curiam). For examples of this instrumentalist view, see, e.g., J. Skelly Wright, Money and the Pollution of Politics: Is the First Amendment an Obstacle to Political Equality?, 82 CoLUM. L. REV. 609, 625-42 (1982). For an example of a broader instrumentalist view, see Owen $M$. Fiss, Free Speech and Social Structure, 71 IOWA L. REV. 1405 (1986). 
assumptions of campaign finance reform advocates, rather than the mechanics or structure of regulation. Further, this Essay argues that it is actually campaign finance regulation that is in conflict with accepted notions of equality, so much so as to be broadly characterized as undemocratic. Regulatory reform efforts thus fail to accomplish even those goals that, under the reformers' instrumentalist First Amendment theory, justify limitations on speech. Beyond asserting the failure of the reformers' program on their own terms, this Essay argues that First Amendment protection, applied unflinchingly to political activity such as campaign contributions and spending, is not a barrier to greater political equality or to the rooting out of corruption, but is a considered instrumentalist response to these problems.

The longstanding agenda of the campaign finance reform movement has been to lower the cost of campaigning, reduce the influence of special interests in both elections and the legislative process, and open up the political system to change. ${ }^{5}$ Reformers have sought to accomplish this primarily through campaign contribution and expenditure limits and, ultimately, through public funding of political campaigns. In 1974, the reform movement seemed to achieve its greatest victory with the passage of major amendments to the Federal Elections Campaign Act (FECA). ${ }^{6}$ Many FECA provisions were soon echoed in state legislation around much of the nation. ${ }^{7}$ Yet the reformist agenda remained unfulfilled. Between 1977 and 1992, congressional campaign spending increased by $347 \% .{ }^{8}$ Congressional election contributions by political action committees (PACs) increased from $\$ 20.5$ million in $1976^{9}$ to $\$ 189$ million in $1994 .{ }^{10}$ Since 1974 , the number of federal PACs has increased from $608^{11}$ to over $4500 .^{12}$ House incumbents, who in 1976 outspent challengers by a ratio of 1.5 to 1 , in 1992 outspent challengers by almost 4 to

5. Frank J. Sorauf, Politics, Experience, and the First Amendment: The Case of American Campaign Finance, 94 Colum. L. REv. 1348, 1357 (1994); Wertheimer \& Huwa, supra note 3, at 45.

6. Wertheimer \& Huwa, supra note 3, at 45.

7. Many of FECA's provisions, however, were quickly declared unconstitutional by the Supreme Court in Buckley v. Valeo, 424 U.S. 1 (1976) (per curiam). See infra notes $45-46$ and accompanying text. Reform advocates have, with some justification, argued that Buckley's elimination of some of FECA's most important provisions explains the apparent failure of reform efforts. I will attempt to show that, even apart from the Buckley Court's holding, FECA was inherently flawed.

8. Spending Explodes Since Reform, CAMPAIGNS \& ElECTIONS, June-July 1993, at 1, 1. However, spending did level off, and even declined in terms of inflation-adjusted dollars, in the late 1980s. See David S. Broder, Campaign Finance Farce, WASH. PosT, May 3, 1992, at C7.

9. Frank J. Sorauf, Political Parties and Political Action Committees: Two Life Cycles, 22 ARIZ. L. REV. 445, 451 (1980).

10. Final Tabulations: PACs Contributed \$189.4 Million to Congressional Candidates During 1993-94 Election Cycle, Pol. Fin. \& LobBY ReP., Apr. 12, 1995, at 1,1.

11. Wertheimer \& Huwa, supra note 3 , at 48.

12. A. Martin Willis, Penniless PACs: Why Do They Bother to Exist?, Pol. FIN. \& LoBBY REP., Nov. 9, 1994, at 1, 3 (indicating number of PACs filing Federal Election Commission (FEC) reports in first 18 months of election cycle). 
$1 .{ }^{13}$ Meanwhile, incumbent reelection rates reached record highs in the House in 1984 and 1988 , before declining slightly in the 1990s. ${ }^{14}$

Despite the apparent failings of the 1974 FECA amendments, critics of reform measures have generally accepted, at least on a theoretical level, that reform can accomplish its goals. ${ }^{15}$ Rather, their objections to reform have focused either on the First Amendment ${ }^{16}$ or on the difficulty of controlling for "unintended consequences." 17

However, the problem with campaign finance reform is not merely unanticipated consequences; rather, at their core, reform efforts are based on faulty assumptions and are, in fact, irretrievably flawed. ${ }^{18}$ Reform proposals inherently favor certain political elites, support the status quo, and discourage grassroots political activity. Even if these proposals worked as intended, they would have an undemocratic effect on American elections.

Part II of this Essay provides a brief historical overview of campaign finance patterns. The legal literature on campaign finance reform is happily uncluttered by any serious consideration of life much before FECA's 1974 amendments. Therefore, a brief review of the historical patterns of campaign finance is necessary to place in perspective the reformers' claims of a serious

13. Wertheimer \& Manes, supra note 3, at 1133.

14. Cass R. Sunstein, Political Equality and Unintended Consequences, 94 CoLUM. L. REv. 1390, 1402 tbl. 2 (1994).

15. See, e.g., Lillian R. BeVier, Money and Politics: A Perspective on the First Amendment and Campaign Finance Reform, 73 CAL. L. REv. 1045 (1985). Professor BeVier finds reformists' legal arguments lacking under traditional First Amendment analysis. However, BeVier admits that she "has deliberately not addressed what is of course the most profound issue: whether political freedom as we have known it can in principle be reconciled with active legislative pursuit of equality of political influence." Id. at 1090.

16. See, e.g., BeVier, supra note 15; Richard A. Epstein, Property, Speech, and the Politics of Distrust, in THE BILL OF RIGHTS IN THE MODERN STATE 41 (Geoffrey R. Stone et al. eds., 1992) (invoking concepts of natural rights and property rights as well as speech rights in opposition to regulation of campaign finance); Daniel D. Polsby, Buckley v. Valeo: The Special Nature of Political Speech, 1976 SUP. CT. REV. 1 (arguing that campaign contributions should be considered speech entitled to full First Amendment protection).

17. See, e.g., Michael J. Malbin, Looking Back at the Future of Campaign Finance Reform: Interest Groups and American Elections, in MONEY AND POLITICS IN THE UNITED STATES: FINANCING ELECTIONS IN THE 1980S 232, 232 (Michael J. Malbin ed., 1984); Roy A. Schotland, Proposals for Campaign Finance Reform: An Article Dedicated to Being Less Dull Than Its Title, 21 CAP. U. L. REV. 429, 436-37 (1992); Sunstein, supra note 14, at 1390. Schotland and Sunstein generally support reform efforts, but argue that reformers have not been sensitive enough to manipulation of reform by incumbents, see Schotland, supra, at 443; Sunstein, supra note 14, at 1400 , and the possibility that campaign finance laws might be circumvented, see id. at 1403-11. Stephen Gottlieb, whose critique comes closest to my own, expresses broad concern that reformers have promoted major changes in our democratic processes without a solid understanding of the empirical results of proposed reforms. See Stephen E. Gottlieb, The Dilemma of Election Campaign Finance Reform, 18 HOFSTRA L. REv. 213, 213-14 (1989). He suggests that there is simply no way to define in advance the resources that any group deserves, and that all proposals to limit spending and contributions will therefore produce unintended consequences that are often detrimental, "both to the goals of the reformers and the values traditionally cherished in first amendment jurisprudence." Id. at $214-16$.

18. This Essay will focus primarily on the regulation of federal campaigns, recognizing that many states have adopted similar regulatory schemes with similar negative effects. These state laws share the assumptions and basic structure of the federal regime. For a brief summary of state regulation, see FrANK SORAUF, MONEY IN AMERICAN ElECTIONS 285-90 (1988). 
modern-day "crisis" in American democracy and to provide a background against which to evaluate reformist assumptions about the role and effects of money. Part III discusses the reformers' basic assumptions and identifies their weaknesses. Part IV describes how campaign finance reform based on these faulty assumptions leads to political results that can be broadly characterized as undemocratic. Part $V$ argues that public financing of elections suffers from the same weaknesses as does campaign finance reform in general. The Essay concludes with the suggestion that the policy difficulties that allegedly necessitate substantial campaign finance regulation are already addressed through the First Amendment, which provides for robust freedom of action and debate in the political arena. The First Amendment ought to be examined not as a libertarian constitutional barrier blocking necessary regulation, but as a considered response to the problems of political corruption and equality and, therefore, the problems posed by campaign finance.

\section{A BRIEF History of the FinANCING AND Regulation OF AMERICAN CAMPAIGNS}

The debate in legal journals over campaign finance regulation is carried on with surprisingly little awareness of the history of financing elections. ${ }^{19}$ History, however, can be useful in putting supposedly modern issues in perspective. It sometimes seems that supporters of campaign finance would be shocked to discover that our nation survived for over one hundred years with no campaign finance laws. ${ }^{20}$ Reformers often operate on the assumption that American democracy faces a unique modern crisis caused by the influence of money in politics. ${ }^{21}$ In fact, reformist concerns are not new. The current campaign finance "crisis" is in fact nothing of the sort, but instead the result of public misperceptions, fueled by the rhetorical fervor of campaign finance reform advocates.

19. For example, one can peruse four recent symposia on campaign finance reform and find no reference at all to how political campaigns were funded prior to World War II. See Symposium on Campaign Finance Reform, 94 CoLUM. L. REV. 1126 (1994); Symposium on Political Expression, 21 CAP. U. L. REv. 381 (1992); Frameworks of Analysis and Proposals for Reform: A Symposium on Campaign Finance, 18 HOFSTRA L. REV. 213 (1989); Symposium, Money in Politics: Political Campaign Finance Reform, 10 HASTINGS CONST. L.Q. 463 (1983).

20. Professor Roy Schotland relates an amusing story about Eugene McCarthy, in which McCarthy imagines Common Cause founder John Gardner sitting with Thomas Jefferson at the writing of the Declaration of Independence. Jefferson turns to Gardner and says,

"Well, John, how's this: 'We pledge our lives, our fortunes, and our sacred honor'. . Quite

fine, is it not?"

"Yes Tom . . . but I believe it would be finer if it read "We pledge our lives, our sacred honor, and our fortunes up to $\$ 1,000$ per annum." Schotland, supra note 17 , at 438 n.18.

21. See, e.g., the title of Fred Wertheimer's most recent piece, Campaign Finance Reform: A Key to Restoring the Health of Our Democracy. See Wertheimer \& Manes, supra note 3. Wertheimer argues that dependency on special interest money is "central to the crisis in public confidence that faces our government" and is a "fundamental problem of our political system." Id. at 1127 . 
In early U.S. elections, most campaign expenses were paid directly by the candidates. Such expenses were relatively minimal, going toward an occasional campaign pamphlet and, especially in the South, food and drink for voters at public gatherings and rallies. ${ }^{22}$ Candidates did not "run" for election, but "stood" for office, relying on their reputations and personal recommendations to carry them to victory. ${ }^{23}$ Though free from the "corrupting" effects of money, elections in this early period were generally contested by candidates representing aristocratic factions standing for election before a relatively small, homogeneous electorate of propertied white men.

This genteel system of upper-class politics began to change in 1828 , when Martin Van Buren organized the first popular mass campaigns around Andrew Jackson and the Democratic party. It was Van Buren's democratization of the process that created the need for significant campaign spending. Money became necessary not only for the traditional expenditures on food and liquor, but also for newspaper advertisements, widespread pamphleteering, rallies, and logistical support. ${ }^{24}$ Even these new, mass parties, however, obtained financing from a small number of sources. Funding for the new style of public campaigning initially came from those who benefited most directly from gaining or retaining power-government employees. Absent a professional civil service, most government employees depended for their jobs on their party's staying in office. It became common practice to assess these employees a percentage of their salaries to support their party's campaigns. ${ }^{25}$ Similarly, would-be officeholders allied with the opposition served as a major source of challengers' funds. ${ }^{26}$ In 1878 , roughly ninety percent of the money raised by the Republican congressional committee came from assessments on federal officeholders. ${ }^{27}$ However, after the passage of the Pendleton Act in 1883, which created a federal civil service, and the adoption of similar laws in the states, campaign money from assessments on officeholders gradually dried up. ${ }^{28}$ Only then did politicians look for new sources of funds. Two dominant groups of donors emerged: wealthy individuals and corporations.

In the latter part of the nineteenth century, government regulation and corporate growth formed a symbiotic relationship. The acceleration of Northern industrialization that accompanied and followed the Civil War created the new phenomenon of the large, national corporation. Wartime government contracts

22. George Thayer, Who Shakes the MONey TREe? 25 (1973).

23. Robert E. Mutch, Campaigns, Congress, and Courts: The Making of Federal Campaign FINANCE LAW at XV (1988).

24. See Donald B. Cole, The Presidency of ANDREW JaCkSON 17-21 (1993); NATHAN Miller, STEALING FROM AMERICA: A HISTORY OF CORRUPTION FROM JAMESTOWN TO REAGAN 116-17 (1992).

25. See MUTCH, supra note 23 , at xvi; THAYER, supra note 22 , at 38.

26. See SORAUF, supra note 1 , at 2-3.

27. Id.

28. Id.; see also JAMES K. POLlOCK, JR., PARTY CAMPAIGN FUNDS 113-25 (1926) (providing detailed description of methods used to collect such assessments and of slow decline in assessments' importance after introduction of civil service reform). 
and increasingly common land and cash grants to railroad companies created the foundations for many of these enterprises.$^{29}$ Corporations also benefited as Republican Congresses sheltered many industries behind high tariff walls. ${ }^{30}$ To tame the corporate power it had helped to create, Congress expanded the sphere of federal regulation. Thus, for example, it created the Interstate Commerce Commission in 1881 and passed the Sherman Antitrust Act in 1890. Simultaneously, state regulation of railroad rates, business competition, and working conditions became common. ${ }^{31}$

With the growth of state and federal government powers, including the increased regulation and subsidization of industry, corporate America recognized the need for increased political participation. ${ }^{32}$ The stated goal was not to buy legislative votes, but to elect candidates supportive of corporate interests. ${ }^{33}$ In 1888 , roughly $40 \%$ of Republican national campaign funds came from Pennsylvania manufacturing and business interests. ${ }^{34}$ State parties were probably even more reliant on corporate funding. By 1904, corporate contributions constituted over $73 \%$ of Theodore Roosevelt's presidential campaign funds. The Democratic party relied less on corporate contributions but was also heavily dependent on financing from the personal wealth of a handful of prominent businessmen. Industrialist Thomas Fortune Ryan $(\$ 450,000)$ and banker Augustus Belmont $(\$ 250,000)$ contributed roughly three-quarters of the Democrats' 1904 presidential campaign fund; Henry Davis, a mine owner and the party's vice-presidential candidate, was another substantial contributor. ${ }^{35}$ Twenty-four years later, in 1928, the Democratic National Committee still received $69.7 \%$, and the Republican National Committee received $68.4 \%$, of their contributions in amounts of $\$ 1000$ or more. ${ }^{36}$

Growing concern about alleged corporate domination of the political process created a demand for regulation, and the first state laws regulating campaign finance were passed in the latter part of the nineteenth century. These laws were typically limited to minimal requirements to disclose

29. Lloyd J. Mercer, Railroad Land Grants, in ENCYCLOPEDIA OF AMERICAN BUSINESS HISTORY AND BIOGRAPHY: RALLROADS IN THE AGE OF REGULATION, 1900-1980, at 353 (Keith L. Bryant, Jr. ed., 1988).

30. Daniel K. Tarullo, Law and Politics in Twentieth Century Tariff History, 34 UCLA L. REv. 285, 286 (1986).

31. See, e.g., STUART ChASE, Government IN Business 25 (1935).

32. THAYER, supra note 22 , at $30-31$.

33. See, e.g., Stephen A. Salmore \& Barbara G. Salmore, Candidates, Parties and CAMPAIGNS: ElECTORAL POLITICS IN AMERICA 29 (1985) (noting willingness of business to spend large sums in 1896 to protect itself from "the populist threat"); THAYER, supra note 22, at 49 ("[B]usinessmen flocked enthusiastically to McKinley because he was one of them.").

34. MUTCH, supra note 23 , at xvii.

35. Id. at 3. Ryan and Belmont were good for another $\$ 80,000$ and $\$ 250,000$, respectively, in 1908 . THAYER, supra note 22, at 54. Candidates such as Davis were often expected to finance a portion of their own campaign as a cost of gaining the party's nomination. SORAUF, supra note 1, at 2-3.

36. SORAUF, supra note 1, at 3 (citing LOUISE OVERACKER, MONEY IN ELECTIONS 133 (1932)). In $1928, \$ 1000$ was enough to pay cash for two new automobiles. Id. 
campaign donations and expenditures, although four states went so far as to ban all corporate contributions beginning in the $1890 \mathrm{~s} .{ }^{37}$ The first federal law, a narrow provision banning some corporate contributions, was passed in 1907. ${ }^{38}$ Over the next six decades, the federal government passed several laws requiring the disclosure of contributions and the filing of reports, but these laws remained generally toothless and were largely ignored..$^{39}$

Most campaigns continued to be funded by small groups of donors. Although a handful of candidates, such as Barry Goldwater in 1964, were able to raise large sums from a broad base of small donors, large contributions continued to dominate campaign fund-raising. ${ }^{40}$ In 1968, for example, insurance executive Clement Stone and his wife contributed $\$ 2.8$ million to Richard Nixon's successful presidential campaign. ${ }^{41}$

Gifts such as the Stones', plus the perceived need to "do something" in the wake of the Watergate scandal, brought about the 1974 FECA amendments, the toughest and most thorough federal campaign-regulation measures ever passed. ${ }^{42}$ The 1974 amendments limited individual, political party, and PAC contributions to candidates, limited personal spending by candidates, placed ceilings on overall campaign spending for federal offices, and limited independent spending by groups not affiliated with a candidate or campaign. ${ }^{43}$ The 1974 amendments also established the public funding mechanism for the presidential election of federal matching funds for primary candidates and federal funds for the general-election campaign. ${ }^{44}$

In fact, the comprehensive scheme enacted in the 1974 amendments was never fully implemented. In Buckley v. Valeo ${ }^{45}$ the Supreme Court struck down on First Amendment grounds the limits on independent spending, limits on a candidate's spending of personal funds, and mandatory campaign spending ceilings. Only the contribution limits, the disclosure requirements, and the voluntary system of public funding of presidential races survived the legal challenge. ${ }^{46}$ Nevertheless, the basic FECA framework remains at the core of most campaign finance reform proposals: limits on contributions, limits on total spending, and the use of public funding. Some reformers argue for

37. MUTCH, supra note 23 , at xvii.

38. Id. at $1-8$.

39. SORAUF, supra note 1, at 5-6. Sorauf notes that there was not a single prosecution under the 1925 federal disclosure law, ultimately repealed in 1971. Id. at 6 . For a detailed account of the evolution of federal law prior to 1971 , see MUTCH, supra note 23 , at $1-42$.

40. SORAUF, supra note 1 , at $3-4$.

41. Id. at 4.

42. Id. at 4-9.

43. Federal Election Campaign Act Amendments of 1974, Pub. L. No. 93-443, 88 Stat. 1263.

44. Id.

45. 424 U.S. 1 (1976) (per curiam).

46. See id. at $3-5$. 
outright reversal of the Court's Buckley decision, ${ }^{47}$ while others have attempted to design contribution and spending limits within the confines of Buckley. ${ }^{48}$ Underlying these different approaches is the common theme that contribution and spending limits are necessary to reduce the influence of large contributors within the political system and thereby to address the current "crisis."

The belief that modern campaigns have been corrupted by big money in some unprecedented manner simply does not square with historical fact. The role of the small contributor in financing campaigns may border on insignificant, but it has increased, rather than declined, over the years. For most voters, familiarizing themselves with the candidates and voting in elections have always been the extent of their political involvement. Thus, for over 200 years, candidates have relied on a small base of donors who hoped to benefit directly from their preferred candidates' election, whether through a public appointment or a higher tariff. When reformers suggest that money is "distorting" our election process, ${ }^{49}$ it is not clear to what norm they refer. ${ }^{50}$

It has been suggested that the modern "American Dilemma" is the conflict between our acceptance of economic inequalities and our commitment to political equality. ${ }^{51}$ However, this brief history of campaign finance patterns illustrates that such tension has long existed in elections, though campaign finance reformers now argue that it has created a "crisis" of American democracy. ${ }^{52}$ Indeed, the rhetoric of reform has changed little since the early part of this century. ${ }^{53}$ It is hard, then, to blame the recent failure to enact reform legislation for any current "crisis."

47. See, e.g., Vincent Blasi, Free Speech and the Widening Gyre of Fund-Raising: Why Campaign Spending Limits May Not Violate the First Amendment After All, 94 COLUM. L. REV. 1281, 1324 (1994); Sunstein, supra note 14 , at 1400; Wright, supra note 4, at 644-45.

48. See, e.g., Lowenstein, supra note 3 , at 351-60.

49. See Cass R. Sunstein, The Partial Constitution 84 (1993) ("Many people think that the present system of campaign financing distorts the system of free expression . . . ."); Paul G. Chevigny, The Paradox of Campaign Finance, 56 N.Y.U. L. REV. 206, 226 (1981) (book review) ("[T]o continue the present system of campaign financing . . . is to perpetuate a system by which money skews the democratic process.").

50. BeVier, supra note 15 , at 1073-74.

51. See Schotland, supra note 17, at 435 (alluding to GunNar MYRDAL, AN AMERICAN Dilemia: The Negro Problem AND MODERN DEMOCRACY (1944)).

52. I do not propose to address in this Essay various arguments that the United States is a repressive society in which a small ruling class has controlled the masses through a corrupt political and economic system. See, e.g., Derrick BELl, Confronting AuTHority (1994). Nor do I attempt, in this Essay, to rebut the recently argued proposition that the Constitution actually requires public funding of the electoral process. See Jamin Raskin \& John Bonifaz, The Constitutional Imperative and Practical Superiority of Democratically Financed Elections, 94 CoLuM. L. REV. 1160, 1164-74 (1994). The former critique represents a fundamental challenge to our society that goes far beyond campaign finance. The latter is an interesting proposition that cannot be fairly addressed in this Essay, other than to point out that if my criticisms of public financing and limits on private spending are correct, Raskin and Bonifaz's argument must fall, based as it is on the premise that the Constitution requires a "democratic" method of elections that cannot be attained absent public financing. See id.

53. See, e.g., OVERACKER, supra note 36, at 376 ("Unless we can find substitute sources for financing campaigns, popular control is threatened."). 
In fact, one might go even further and speculate that existing campaign finance reform is contributing to the current crisis of confidence in government. It is over the past thirty years, simultaneously with the growth of campaign finance regulation, that public confidence in government has plunged. ${ }^{54}$ I certainly do not mean to suggest that the perceived crisis of confidence is solely, or even primarily, caused by campaign finance regulation. Correlation must not be confused with causation, and Vietnam, Watergate, Abscam, Iran-Contra, Waco, bounced checks, absurd regulation, ${ }^{55}$ the unchecked growth of federal spending and debt, and any number of other factors are equal or more plausible candidates to explain the decline of confidence in the government. But where the prescribed remedy seems to correlate with the rise of the disease, it is only prudent to reexamine the assumptions upon which that remedy is based. ${ }^{56}$

Reformers have failed to show why a system of campaign finance that has existed throughout the nation's history must be overturned. They have failed to prove that new, unique circumstances justify infringement of First Amendment rights, or even that these infringements will cure the alleged ills. Professor Lowenstein has argued, with some merit, that opponents of reform have subjected reformers' proposals to a higher level of scrutiny than these critics could themselves withstand. ${ }^{57}$ But reformers justifiably face such a heavy burden. It is they who seek to change longstanding norms of campaign financing and political activity. It is they who seek to impose an ever growing list of First Amendment infringements on society. The next part analyzes the validity of the assumptions that, according to the reformers, justify such First Amendment infringements.

\section{FAULTY ASSUMPTIONS OF CAMPAIGN FINANCE REFORMERS}

Four general assumptions underlie the arguments made in favor of campaign finance regulation: First, there is too much money being spent in

54. See Ronald Brownstein, Clinton's Job One: Reversing the Anti-Government Tide, PUB. PERSP., May/June 1994, at 3, 3-4.

55. Quibblers on this point are directed to PHILIP K. HOWARD, THE DEATH OF COMMON SENSE: How LAW IS SUFFOCATING AMERICA (1994). I assume that the other items in this list need no citation.

56. Reformers argue, correctly, that Buckley $v$. Valeo prevented a comprehensive reform system from ever taking shape by striking down spending limits and limits on independent expenditures. However, given that the Court has shown no sign of retreating from Buckley, reformers must consider their proposals, and the likely consequences thereof, within the Buckley framework. Furthermore, while we cannot be certain what the empirical data might show had Buckley left the entire FECA scheme intact, it should be apparent to the reader on a theoretical level that most of the negative consequences of campaign finance reform efforts would apply regardless of Buckley. A few, obviously, would not, such as the tendency of contribution limits, coupled with no limits on candidate personal spending, to favor wealthy candidates. But most would apply, often more strongly, given that the 1974 FECA reforms were based on the flawed assumptions identified in this Essay. See Sorauf, supra note 5, at 1356. For an example of the misguided literature in the debate leading up to the passage of the 1974 legislation, see JOHN W. GARDNER, IN COMMON CAUSE 33-40, 55-57 (1972).

57. See Lowenstein, supra note 3, at 303-04. 
political campaigns; ${ }^{58}$ second, campaigns based on small contributions are, in some sense, more democratic, more in touch with the "people," than campaigns financed through large contributions, 59 third, money buys elections, presumably in a manner detrimental to the public good; ${ }^{60}$ and fourth, money is a corrupting influence on the legislature. ${ }^{61}$ Given these assumptions, it is believed that the end result of an unregulated finance system will be a political process increasingly dominated by wealthy individuals whose interests are at odds with those of ordinary citizens. ${ }^{62}$ But are these assumptions warranted? This part of the Essay will examine each of them in turn and conclude that each one is seriously flawed.

\section{A. Assumption One: Too Much Money Is Spent on Campaigns}

One often hears that too much money is spent on political campaigns. ${ }^{63}$ The language in which campaigns are described in the general press constantly reinforces that perception. Candidates "amass war chests" with the help of

58. See GARDNER, supra note 56 , at 38,56 .

59. See id. at 55 .

60. Cf. id. at 38-39 (arguing that candidates must appeal to monied interests).

61. See id. at $41-42$.

62. See DREW, supra note 2, at 5; Sunstein, supra note 14, at 1392-93; Wertheimer \& Manes, supra note 3 , at 1126-27.

63. See, e.g., Schotland, supra note 17 , at 443 . This view is certainly popular among the general public. One recent poll found that $90 \%$ of respondents agreed with the proposition that "there's way too much money in politics." Tẻrry Ganey, To Campaign Finance Reform Advocates, the Webster Scandal Was Proof Positive Proposition A Would Limit Donations, Aiming to Cut Big Money's Political Role, ST. LouIS POST DISPATCH, Oct. 23, 1994, at 1B. I poll my students on the first day of my election law class, and have found that approximately $75 \%$ will "agree" or "strongly agree" with the statement, "Too much money is spent on political campaigns."

Nevertheless, Professor Nicholson agrees that spending on campaigns is not excessive and suggests that such an argument is a "non-battle .... No thoughtful student of campaign finance will dispute ... this point, despite the fact that demagogues may occasionally still argue to the contrary." Nicholson, supra note 3, at 473; see also Lowenstein, supra note 3, at 350 (arguing that restricting PAC contributions would require replacement source of revenue). However, as Professor Nicholson also notes, "reform proposals designed by Democrats in Congress routinely include overall expenditure limitations." Nicholson, supra note 3 , at 473 . While Nicholson may be convinced that we do not spend too much on campaigns, many reformers are not. See, e.g., Debra Burke, Twenty Years After the Federal Election Campaign Act Amendments of 1974: Look Who's Running Now, 99 DiCk. L. REv. 357, 375-76 (1995); Wertheimer \& Manes, supra note 3, at 1132-33; Kenneth J. Levit, Note, Campaign Finance Reform and the Return of Buckley v. Valeo, 103 YALE L.J. 469, 473 (1993) ("[Buckley] ignored the role excessive campaign spending plays in compromising the electorate's confidence in the democratic process."); see also Sorauf, supra note 5, at 1357 ("[A] consensus agenda for mainstream reform . . . includes . . . a reduction in the total sums being raised and spent on contemporary campaigns ....").

Furthermore, even reformers such as Nicholson tend to favor contribution limits. As Professor Lowenstein has discussed, such limits, set low enough, will have the effect of restricting overall spending. See Daniel H. Lowenstein, A Patternless Mosaic: Campaign Finance and the First Amendment After Austin, 21 CAP. U. L. REv. 381, 399-401 (1992). Most reform proposals include contribution limits. And Professor Nicholson herself is ready to accept overall spending limits as part of a reform package. See Nicholson, supra note 3 , at 475 .

Thus, less careful reformers and much of the public believe that too much is spent; more thoughtful reformers may not believe that too much is spent, but they see little harm in further restricting spending. Either way, the assumption is incorrect. 
"special interests" that "pour" their "millions" into campaigns. "Obscene" expenditures "careen" out of control or "skyrocket" upwards. "This language notwithstanding, there is actually good cause to believe that we do not spend enough on campaigns.

The assertion that too much money is spent on campaigning essentially begs the question: Compared to what? Compared to yogurt or potato chips? Americans spend more than twice as much money each year on yogurt, ${ }^{65}$ and two to three times as much on the purchase of potato chips, ${ }^{66}$ as they do on political campaigns. In the two-year election cycle culminating in the elections of November 1994, approximately $\$ 590$ million was spent by all congressional general-election candidates combined. ${ }^{67}$ Although this set a new record for spending in congressional races, the amount is hardly exorbitant, amounting to roughly $\$ 3$ per eligible voter spent over the two-year period between elections. Total direct campaign spending for all local, state, and federal elections, including congressional elections, over the same period can be reasonably estimated as between $\$ 1.5$ and $\$ 2.0$ billion, or somewhere between $\$ 7.50$ and $\$ 10$ per eligible voter over the two-year cycle. ${ }^{68}$ When one

64. See, e.g., SORAUF, supra note 1, at 26; Wertheimer \& Manes, supra note 3, at 1132-33.

65. See George F. Will, So We Talk Too Much, NEwsweEK, June 28, 1993, at 68, 68 (observing that total cost of 1992 congressional races equaled $40 \%$ of what Americans spent on yogurt that year).

66. Clare Ansberry, The Best Beef Jerky Has Characteristics Few Can Appreciate, WaLl ST. J., Apr. 4,1995 , at $A 1, A 12$ (noting annual spending on potato chips in excess of $\$ 4.5$ billion).

67. Post-election Reports Point to New Records, POL. FIN. \& LOBBY REP., Dec. 28, 1994, at 1, 1 [hereinafter Post-election Reports]. This only includes total spending by victorious primary candidates. An additional $\$ 76$ million was spent by losing primary election candidates. Id. at 5 .

68. Herbert Alexander and Anthony Corrado estimate total direct spending on all local, state, and federal campaigns for the 1991-92 cycle (not including ballot issues and the presidential campaign) at $\$ 1.543$ billion. DaNiEL H. LoweNSTEIN, Election LAW: CASES AND Materials 478 (1995) (citing HERBERT E. AlEXANDER \& ANTHONY CORRADO, FinANCING THE 1992 EleCTION (1995)). Approximately $\$ 950$ million is spent on party organization and administration and political action committee overhead. Id. at 477-78. Spending on congressional races increased by roughly 17\% from the 1991-92 to the 1993-94 cycle. Post-election Reports, supra note 67, at 1,5. Applying a similar rate of increase to Alexander and Corrado's figures for state and local races in 1991-92, total direct campaign spending at all levels in 1993-94 would have been approximately $\$ 1.8$ billion.

In recent years, the reform literature has expressed growing concern about "soft money" in campaigns. See, e.g., Wertheimer \& Manes, supra note 3, at 1144-48 (arguing that "soft money" threatens integrity of presidential and congressional campaigns). In fact, "soft money" is a small part of total spending, approximately $\$ 83$ million in $1991-92$, or about $4.5 \%$ of the amount of direct spending. Marty Jezer \& Ellen Miller, Money Politics: Campaign Finance and the Subversion of American Democracy, 8 NoTRE DAME J.L. ETHICS \& PUB. POL'Y 467, 489-90 (1994) (citing JOSHUA GOLDSTEIN, SOFT MONEY, REAL DOLLARS: SOFT MONEY IN THE 1992 ELECTIONS 3-4 (1993)). The arguments against soft money are the same as those against direct contributions (though one additional criticism applicable to soft money and not to other types of contributions is the absence of reporting requirements for soft money, see Wertheimer \& Manes, supra note 3, at 1144-45), and therefore do not change the terms of the debate. In fact, soft money actually has several advantages over direct contributions. To the extent reformers are concerned about the potential corrupting effects of campaign contributions, soft money, which is given to the parties, should ameliorate that perceived problem. It allows parties to channel their funds into competitive races and do generic party advertising, which may be beneficial for electoral competition, $c f$. Lowenstein, supra note 3, at 354-55 (arguing that generic party advertising has potential to move political system toward responsible party government), and it may increase party discipline by making candidates more reliant on their parties, which many political scientists view as a good thing, see, e.g., LEON D. EPSTEIN, POLITICAL 
considers that this per-voter figure is spread over several candidates for which that voter is eligible to cast a ballot, it is hard to suggest that office seekers are spending "obscene" sums attempting to get their messages through to voters.

Comparisons to levels of corporate spending on product advertising help to illustrate that spending on political campaigns is minimal. The sum of the annual advertising budgets of Procter \& Gamble and Philip Morris Company, the nation's two largest advertisers, is roughly equal to the amount spent by all federal and state political candidates and parties in a two-year election cycle $^{69}$ The value of such comparisons can be disputed: If one views the problem as the allegedly corrupting effect of campaign money, then the suggestion that it may take less to buy politicians than to sell soap and tobacco provides little comfort. But such numbers are useful to put political spending into perspective when it is the raw levels of spending that are challenged, and to consider the probable effect on political communication of reform measures that would limit spending. ${ }^{70}$

Increased campaign spending translates into a better-informed electorate. Gary Jacobson's extensive studies have shown that "the extent and content of information [voters] ... have has a decisive effect on how they vote."? Voters' understanding of issues increases with the quantity of campaign information received. ${ }^{72}$ In short, spending less on campaigns will result in less public awareness and understanding of issues.

Accepting the premise that too much money is not being spent in absolute terms, one searches for an explanation as to why the public perception differs from the reality. It may be fairly suggested that the perception stems from a belief that what money is spent is largely ineffective or even destructive. In other words, the perceived problem, on closer examination, may not be that too much is spent, but that too little benefit is received in return. In particular, high

PARTIES IN THE AMERICAN MOLD 3 (1986) (noting that most observers view parties as "organizationally desirable and probably essential in a democratic nation").

69. Schotland, supra note 17 , at 444 (using 1987-88 data).

70. Also, one can have a lot of fun with such numbers. For example, Sony Music International will spend some $\$ 30$ million, or about the cost of Michael Huffington's 1994 U.S. Senate campaign, to promote a Michael Jackson CD with the lyrics, "'Jew me, sue me, everybody do me, kick me, Kike me, don't you black or white me." See Sony's Statesmanship, WALL ST. J., June 20, 1995, at A18. Or one can cite the $\$ 100$ million, more than the cost of a presidential campaign, being spent in 1995 to promote reruns of the situation comedy, "Seinfeld." See Roxanne Roberts, The Remote Controllers; Meet the Folks Who Keep You Tuned to Their Show, WASH. POST, June 10, 1995, at B1.

71. Gary C. JACOBSON, Money IN CONGREsSIONAL Elections 31 (1980).

72. Gottlieb, supra note 17, at 266; see also Wertheimer \& Huwa, supra note 3, at 58 (noting that greater use of television advertising increases electorate's knowledge about candidates and issues and stimulates interest in campaign) (citing Charles Atkin \& Gary Heald, Effects of Political Advertising, 40 PUB. OPINION Q. 216, 228 (1976)). Kentucky officials reported a sharp decline in voter turnout and interest in the 1995 gubernatorial primaries, the first state election after the state passed legislation that reduced campaign spending in 1994. John Harwood, Kentucky's New Campaign-Finance Law Limits Donations as Well as Interest in Governor's Race, WALL ST. J., Oct. 5, 1995, at A16. However, turnout in the November 1995 general election was approximately $44 \%$, about the same as in 1991. Al Cross, Final Tally Trims Patton's Edge, COURIER-JOURNAL (Louisville), Nov. 28, 1995, at 3B. 
spending has been linked to many voters' disgust with what is perceived as the relentless negativity of modern, televised campaign advertisements. ${ }^{73}$

However, efforts to limit spending on campaigns-either directly, through spending limits, or indirectly, through contribution limits-bear no relationship to the negativity of the campaign, and may actually cause an increase in unfair, negative campaigning. Less spending only reduces the amount of communication; it does not mitigate any negative tone that the communication might have. This reduction in the flow of information would tend to make well-produced negative advertising more valuable, as candidates will need to get the maximum political mileage from each expenditure, and as a poorly informed electorate may be more susceptible to misleading political advertisements. More perniciously, candidates who have reached a spending limit, or who cannot tap proven supporters to raise additional funds, may be unable to respond to late, unfair, negative assaults.

Moreover, it is a mistake to assume that the elimination of negative campaigning would necessarily serve the public. Negative advertising that is relevant to the issues can increase public awareness in a positive way. Bruce Felknor notes that without negative campaigning aimed at underscoring an opponent's bad side, "any knave or mountebank in the land may lie and steal his or her way into the White House or any other elective office." distinguishes between "fair" and "unfair" campaigning, based on truth and relevance. $^{75}$ To suggest that candidates should not point to each other's perceived shortcomings, writes Felknor, is "preposterous."76

There are no objective criteria by which to measure whether "too much" is spent on political campaigns. What is spent on campaigns, one might fairly suggest, is the amount that individuals feel it is worthwhile to contribute and

73. See, e.g., Wertheimer \& Manes, supra note 3, at 1130-31 (quoting former Senate Majority Leader George Mitchell on campaign finance reform: "[Americans] see a campaign finance system that places tremendous money demands on those who run ... and a system dominated by negative campaigns."'); Peter F. May, Note, State Regulation of Political Broadcast Advertising: Stemming the Tide of Deceptive Negative Attacks, 72 B.U. L. REV. 179, 187-89 (1992). This perception may itself be influenced by press reporing and editorials critical of campaign advertising. See, e.g., John Balzar \& Doug Conner, With Foley, Noble Era Will End, L.A. TIMES, Nov. 10, 1994, at A1, A17 (asserting that negative ads, along with special interest intrusion, constitute "the dark streak of American campaign politics"); Stuart Elliott, Ketchum Protests Political Ads, N.Y. TIMES, Nov. 10, 1994, at D23 (quoting advertising executive as saying negative ads are "“political filth that is not advertising and shouldn't be dignified by being called advertising"'); Charles Krauthammer, Political Suicide, WASH. POST, Oct. 28, 1994, at A27 (characterizing political advertising as "virulent, scurrilous, wall-to-wall character assassination"); Robin Toner, Bitter Tone of the '94 Campaign Elicits Worry on Public Debate, N.Y. TIMES, Nov. 13, 1994, at A1 (discussing negative tone of 1994 campaign). But whether modern, televised campaign advertising is overly negative may simply be a matter of individual voter preference. Negative advertising is popular for a simple reason: It works. Indeed, as Bruce Felknor, former Executive Director of the Fair Campaign Practices Committee, has stated, "without attention-grabbing, cogent, memorable, negative campaigning, almost no challenger can hope to win unless the incumbent has just been found guilty of a heinous crime." BRUCE L. FELKNOR, POLITICAL MISCHIEF: SMEAR, SABOTAGE, AND REFORM IN U.S. ELECTIONS 29 (1992).

74. FELKNOR, supra note 73 , at 29.

75. $I d$, at 30 .

76. Id. at 29. 
that candidates find it is effective to raise and spend. Considering the importance of elections to any democratic society, it is hard to believe that direct expenditures of approximately $\$ 10$ per voter for all local, state, and national campaigns, over a two-year period, constitutes a crisis requiring limitations on spending.

\section{B. Assumption Two: Campaigns Funded with Small Contributions Are More Democratic}

Within the reform movement lies a deep-rooted belief that democratic political campaigns should be financed by small contributions. ${ }^{77}$ This position is motivated by the belief that large contributions corrupt either or both the electoral and legislative systems. Such a belief suggests that a campaign funded through small contributions will in the end lead to less corruption. However, small contributions are often seen as an end in themselves, on the notion that even if money were not corrupting, small contributions epitomize the American belief in self-government and participatory democracy. ${ }^{78}$ This notion of the campaign funded through small contributions as the embodiment of representative democracy is unrealistic.

First, this vision appears to be based on an idealized image of democratic politics. As shown in Part II, the burden of financing political campaigns has always fallen on a small minority of the American public. Today, as many as eighteen million Americans make some financial contribution to a political party, candidate, or PAC in a given election cycle. ${ }^{79}$ "No other system of campaign funding anywhere in the world enjoys so broad a base of support." 80 Yet this "broad base of support" amounts to only some $10 \%$ of the voting-age population. ${ }^{81}$ With the exception of the occasional race with a candidate who can whip up an ideological fervor on the fringe of mainstream politics, such as George McGovern or Oliver North, Americans are simply

77. See Sorauf, supra note 5 , at 1356.

78. Id.

79. SORAUF, supra note 1, at 29 (citing data from University of Michigan National Election Study of 1988 election). PACs are widely assailed as the uitimate villains in the reformers' frame of reality. See, e.g., Wertheimer \& Huwa, supra note 3, at 48-53; Wertheimer \& Manes, supra note 3, at 1136-40. In fact, PACs are nothing more than an agglomeration of small contributors, many of whom might not contribute to politics absent PAC solicitation. To the extent that reformers truly believe that campaigns should be funded by small contributions, therefore, PACs ought to be viewed as a positive force. $C f$. LARRY J. SABATO, PAYING FOR ELECTIONS 19-22 (1989) (arguing against limits on PAC donations).

80. SORAUF, supra note 1 , at 30 .

81. Id. at 29 (citing data from University of Michigan National Election Study of 1988 election). This figure has been quite stable for three decades. See generally Ruth S. Jones, Contributing as Participation, in MONEY, ElECTIONS, AND DEMOCRACY 27 (Margaret L. Nugent \& John R. Johannes eds., 1990) (observing that typically $10-12 \%$ percent of electorate donates to campaigns). 
unwilling, individually, to contribute enough money in small amounts to run modern campaigns. ${ }^{82}$

It is a mistake to assume that a broad base of contributors necessarily makes a campaign in some way more representative or more attuned to the popular will. Though the eighteen million who contribute to campaigns constitute a far broader base of financial contributors than existed in the eighteenth and nineteenth centuries, few would argue that this has made the political system more democratic or more responsive. ${ }^{83}$ Indeed, it is an article of faith in reformist literature that our system has grown less responsive to popular will in the last century. In fact, however, those candidates who have been best able to raise campaign dollars in small contributions have often been those who were most emphatically out of the mainstream of their time. Barry Goldwater's 1964 presidential campaign, for example, raised $\$ 5.8$ million from 410,000 small contributors, before going down in a landslide defeat. ${ }^{84} \mathrm{On}$ his way to an even more crushing defeat in 1972, George McGovern raised almost $\$ 15$ million from small donors, at an average of approximately $\$ 20$ per contributor. ${ }^{85}$ And if we assume that reliance on numerous small contributions makes a campaign in some way more "democratic," then the most "democratic" campaign of 1994 was the U.S. Senate campaign of Oliver North. North raised approximately $\$ 20$ million, almost entirely from small contributors, and actually outspent his nearest rival by nearly 4 to $1 .^{86}$ Yet he still lost to an unpopular opponent plagued by personal scandal. ${ }^{87}$ All of these campaigns were among the most prominent extremist candidacies in recent decades. This suggests that the ability to raise large sums in small amounts is a sign of fervent backing from a relatively small minority, rather than a sign of broad public support. At the same time, truly mass-based political

82. See Lowenstein, supra note 3, at 348 (citing Gary Jacobson, Party Organization and Distribution of Congressional Resources: Republicans and Democrats in 1982, 100 AM. POL. SCI. Q. 603, 610 (1985-86)).

83. Cf. Wertheimer \& Manes, supra note 3, at 1129-30 (citing polling data indicating public distrust of politicians).

84. SORAUF, supra note 1 , at 4.

85. Id. Segregationist George Wallace was another prominent figure who raised large sums in small amounts: $\$ 5.8$ million in contributions under $\$ 100$ in his 1968 presidential run. Id.

86. It is interesting to note that despite his reliance on small donations from a large donor base, North was roundly castigated by many campaign finance reformers for the high cost of his campaign. See, e.g., High-cost Campaigns, ST. PETERSBURG TIMES, Nov. 14, 1994, at 8A; Richard Roeper, Hofeld War Chest Filled With Lost Opportunity, ChICAGo Sun-Times, Nov. 9, 1994, at 9.

87. See Michael J. Malbin, Most GOP Winners Spent Enough Money to Reach Voters, PoL. FIN. \& LOBBY REP., Jan. 11, 1995, at 8, 9. 
movements have historically relied on a relatively small number of large contributors for "seed money," if not for the bulk of their funding. ${ }^{88}$

Campaign finance reform efforts tend to overlook the significant collective action problem that prevents most voters from giving financially to candidates. Even if large contributions were totally banned, thereby increasing the relative importance of small contributions, no single contribution would be likely to have a significant impact on an election. ${ }^{89}$ Voters, therefore, still have little rational incentive to make contributions. This collective action problem may be overcome by a radical campaign in which donors are motivated by ideology rather than rational, utility-maximizing calculations. However, in most instances, there will not be sufficient funds available to finance campaigns at a level that informs the electorate unless a resort is made to public funds. ${ }^{90}$ Thus, a system of private campaign finance will almost inevitably come to rely on large individual donors who believe that their substantial gift can make a difference, and on interest groups (i.e., PACs) that overcome voter inertia by organizing voters to address particular concerns. ${ }^{91}$

\section{Assumption Three: Money Buys Elections}

The third assumption of campaign finance reform is that money "buys" elections in some manner incompatible with a functioning democracy. ${ }^{92}$ It seems axiomatic that a candidate with little or no money to spend is unlikely to win most races. Furthermore, the candidate who spends more money wins

88. See Gottlieb, supra note 17, at 220-21; see also infra notes 144-46 and accompanying text. Thayer notes how such progressive turn-of-the-century candidates as Woodrow Wilson, Robert LaFollette, William Jennings Bryan, and Hiram Johnson (who was elected on the slogan "Kick the corporations out of politics") were financed by a small number of wealthy supporters. THAYER, supra note 22, at 54-57. Ross Perot has recently announced his intention to create a new mass party, which will presumably rely on his millions to get started.

89. Cf. Lillian R. BeVier, Campaign Finance Reform: Specious Arguments, Intractable Dilemmas, 94 COLUM. L. REV. 1258, 1274 (1994) (noting that "pervasive collective action problems" discourage Americans from following politics closely).

90. See Lowenstein, supra note 3 , at 350 .

91. BeVier, supra note 89 , at $1274-75$.

92. Within the reformist literature, there is some disagreement over the importance of this issue. Professor Lowenstein, for one, seems relatively comfortable with large monetary contributions made as part of an "electoral" strategy-that is, with the hope of electing sympathizers to office. See Lowenstein, supra note 3, at 308-13. His primary concern is with contributors pursuing a "legislative" strategy, i.e., seeking to influence, rather than to elect, a legislator. See id.; see also Daniel H. Lowenstein, Political Bribery and the Intermediate Theory of Politics, 32 UCLA L. REv. 784, 791-95 (1985). Others seem equally or more concerned with the idea of "buying elections" and with the importance of voter equality. See, e.g., David A. Strauss, Corruption, Equality, and Campaign Finance Reform, 94 CoLUM. L. REv. 1369, 1371-82 (1994); Sunstein, supra note 14, at 1392. Reformers whose primary goal is to reduce the allegedly improper influence of contributions on legislative decisionmaking will be less worried about efforts to elect a candidate who agrees, in principle, with the donor. By contrast, reformers who see equality as the fundamental goal of campaign finance reform will be concerned with efforts to "buy" elections. As Professor Lowenstein notes, equality is an issue that appeals to most political liberals but has little appeal to many conservatives, whereas the potentially corrupting influence of money is generally frowned upon by observers of all political stripes. See Lowenstein, supra note 3, at 346. 
more often than not. ${ }^{93}$ But correlation is not the same as cause and effect, and one must be careful not to make too much of such simple numbers. The correlation between spending and victory may stem simply from the desire of donors to contribute to candidates who are likely to win, in which case the ability to win attracts money, rather than the other way around. ${ }^{94}$ Similarly, higher levels of campaign contributions to, and spending by, a candidate may merely reflect a level of public support that is later manifested at the polls. ${ }^{95}$ Generally speaking, the same attributes that attract voters to a candidate will attract donations, and those that attract donations will attract voters. ${ }^{96}$ In other words, the candidate who is able to raise more money would usually win even if that candidate could not spend the added money: The ability to raise money is evidence of political prowess and popularity that would normally translate into votes, regardless of spending. ${ }^{97}$

At the same time, higher spending does not necessarily translate into electoral triumph. As Michael Malbin puts it, "Having money means having the ability to be heard; it does not mean the voters will like what they hear." ${ }^{\prime 98}$ One need only look at recent elections to prove his point. In the 1994 U.S. House elections, for example, many incumbents won while spending considerably less than their opponents. ${ }^{99}$ More pointedly, the thirty-four Republican challengers who defeated Democratic incumbents spent, on average, only two-thirds of the amounts expended by their opponents, ${ }^{100}$ and one spent less than one-twentieth as much as did his incumbent opponent. ${ }^{101}$ Given the inherent advantages of incumbency, this is powerful evidence that a monetary advantage alone does not mean electoral success.

In support of the assumption that money buys elections, some commentators have recently expressed concern about the "war chest mentality," the tendency of incumbents to amass large campaign funds well in advance of a race in order to scare off challengers. ${ }^{102}$ Recent research by economists Philip Hersch and Gerald McDougall has found that a large

93. See Herbert E. AleXander, Financing Politics: Money, Elections, AND POLITICAL Reform 20 (3d ed. 1984).

94. See Stephanie D. Moussalli, Campaign Finance Reform: The Case for Deregulation 4 (1990); Gary C. Jacobson, Money in the 1980 and 1982 Congressional Elections, in MONEY AND POLITICS IN THE UNITED STATES: FINANCING ELECTIONS IN THE 1980s, supra note 17, at 38, 57.

95. MousSALLI, supra note 94 , at 4.

96. See Gary C. Jacobson, The Effects of Campaign Spending in House Elections: New Evidence for Old Arguments, 34 AM. J. POL. SCI. 334, 342-43 (1990).

97. SORAUF, supra note 18 , at 161-64.

98. Malbin, supra note 87 , at 9.

99. See Late Money in Key House Races, POL. Fin. \& LoBBY REP., Jan. 11, 1995, at 3, 5-6.

100. Malbin, supra note 87 , at 9.

101. Money in House Seat Turnovers, POL. FIN. \& LoBBY REP., Nov. 23, 1994, at 3, 4.

102. See, e.g., Blasi, supra note 47 , at 1284-89. 
incumbent war chest does indeed correlate with a lower likelihood of a serious challenge in U.S. House races. ${ }^{103}$

On closer examination, however, the war-chest argument is merely a variation on the basic assumption that money is the primary determinant of who wins office. In the "war chest" version, one candidate, usually the incumbent, has simply raised cash early enough that opponents do not even try to contest for the seat, recognizing that such a quest is unlikely to succeed. But the war-chest argument, like the basic assumption that money buys elections, still does not account for how or why the incumbent is able to raise large sums early in the election cycle. Hersch and McDougall note that a large campaign fund at an early date tends to indicate that the candidate is popular and has other attributes that make a challenger unlikely to succeed. ${ }^{104}$ An early accumulation of cash also demonstrates a determination by the candidate to run a hard, competitive campaign. Thus a war chest may serve as a signal to potential challengers that the incumbent is popular and determined, and that a challenge is therefore unlikely to succeed. At the same time, it helps to explain why we might not expect a strong challenge even in the absence of a war chest: Good candidates will not waste energy challenging a popular incumbent. $^{105}$

Further, the Hersch/McDougall study indicates that it is not the size of the war chest, but these other qualities, including the candidate's popularity, that diminish the chances of serious challenge. The average war chest in their study was only $\$ 159,000$, rising to just $\$ 203,000$ in races in which the incumbent eventually ran without serious competition. ${ }^{106}$ This second figure barely reaches the lower end of the estimated fund of $\$ 200,000$ to $\$ 500,000$ needed to run a competitive race at the time of the study. ${ }^{107}$ Thus, a challenger would normally have expected the incumbent to spend at least the amount of

103. See Philip L. Hersch \& Gerald S. McDougall, Campaign War Chests as a Barrier to Entry in Congressional Races, 32 ECON. INQUIRY 630, 630-37, 640 (1994) (examining U.S. House races during 1988 election cycle). Hersch and McDougall define a war chest as the amount of cash on hand 11 months before the election, a time when challengers must usually decide whether to pursue a campaign. See id. at 635.

104. See id. at 632.

105. Hersch and McDougall suggest that by discouraging monetary expenditures on futile campaigns against popular incumbents, war chests may actually increase efficiency in the use of campaign resources. See id. at 634. Of course, this overlooks other benefits that may materialize from even a long-shot challenge, such as public awareness of issues and a voting outlet for the minority of voters dissatisfied with the incumbent. For present purposes, the key fact is that the correlation between larger war chests and less competition does not directly support the thesis that money buys elections, but rather underscores the point that otherwise strong candidates can usually raise large sums of money as well.

106. Id. at 635 .

107. See Gary C. Jacobson, Enough is Too Much: Money and Competition in House Elections, in ELECTIONS IN AMERICA 173, 179 (Kay Lehman Schlozman ed., 1987) (estimating that $\$ 500,000$ is needed for challenger to have realistic chance of success in U.S. House campaign in 1986); Larry Sabato, Real and Imagined Corruption in Campaign Financing, in ELECTIONS AMERICAN STYLE 155, 169 (A. James Reichley ed., 1987) (suggesting $\$ 150,000$ was "minimum financial base needed to conduct a modem campaign"). 
the war chest, and probably more, regardless of whether the candidate had the amount on hand well before the election. Moreover, Gary Jacobson's empirical studies have shown that added incumbent spending yields little or no vote gain at certain levels. ${ }^{108}$ Because higher levels of spending would be of little value to the incumbent in any case, any head start gained by amassing a war chest would be of relatively little importance. Thus, challengers are probably not discouraged by the presence of a war chest per se, but by what the early accumulation of campaign funds signifies in terms of tenacity, political ability, and popularity. ${ }^{109}$

The assumption that money buys elections is based on simple correlation: The candidate who spends the most usually wins. However, it would be surprising if this were not the case, as contributions flow naturally to those candidates who are popular and are perceived as having a good chance of winning. It seems clear that many candidates win despite spending less than their opponents, and that the correlation between spending and success is not as strong as other indicators, such as the correlation between incumbency and success. ${ }^{110}$ The problem, if it exists, is not that some candidates "buy" elections by spending too much, but that other candidates spend too little to reach the mass of voters. ${ }^{111}$

\section{Assumption Four: Money Is a Corrupting Influence on Candidates}

A fundamental tenet of the reform movement is that money has corrupted the legislative process in America. ${ }^{112}$ Large numbers of Americans have come to view legislative politics as a money game, in which campaign contributions are the dominant influence on policymaking. ${ }^{113}$

108. See Gary C. Jacobson, The Politics of Congressional Elections 132 (3d ed. 1992); Jacobson, supra note 96, at 349; Jacobson, supra note 94, at 61 .

109. See SORAUF, supra note 1 , at 178 .

110. Id. at $175-76,178$.

111. See id. at 178-79; see also Sabato, supra note 107, at 169. For a further discussion of this point, see infra notes $148-58$ and accompanying text.

112. See, e.g., Lowenstein, supra note 3, at 306-35; Wertheimer \& Manes, supra note 3, at 1126; Wright, supra note 4 , at 609-10.

113. See Wertheimer \& Manes, supra note 3, at 1129-30 (citing polling data). In Buckley, the Supreme Court held that the mere "appearance of corruption" is a constitutionally sufficient justification for infringing on First Amendment rights through campaign finance regulation. Buckley v. Valeo, 424 U.S. 1, 26 (1976) (per curiam). This argument is not particularly persuasive for several reasons.

First, although the importance of appearances is discussed by Wertheimer \& Manes, supra note 3 , at 1130-31, among others, it is not a major argument in the campaign finance reform literature.

Second, the "appearance of corruption" rationale is both unnecessary and dangerous. If the campaign finance system leads to actual corruption, then that may be a constitutionally sufficient justification for the state to infringe on free speech rights, in which case the "appearance of corruption" basis is superfluous. If the campaign system does not lead to actual corruption, then it seems very dangerous to suggest that the mistaken view of some could justify restricting the First Amendment liberties of others. For example, if complete campaign finance reform were insufficient to change the public's erroneous view, would the state then be justified, under a least restrictive means test, in censoring political reporting that wrongly focuses excess attention on money and thus itself creates the "appearance of corruption"? The justification of such 
In many respects, this would seem to be the most sound of the fundamental reformist assumptions. Experience and human nature tell us that legislators, like most people, are influenced by money, even when it goes into their campaign funds rather than directly into their pockets. Many legislators themselves have complained of the influence of money in the legislature. ${ }^{114}$

In fact, however, a substantial majority of those who have studied voting patterns on a systematic basis agree that campaign contributions affect very few votes in the legislature. ${ }^{115}$ The primary factors determining a legislator's votes, these studies conclude, are party affiliation, ideology, and constituent views and needs. ${ }^{116}$ Where contributions and voting patterns intersect, they do so largely because donors contribute to those candidates who are believed to favor their positions, not the other way around. ${ }^{117}$

These empirical results cut against our intuitions. Yet to accept the findings of these repeated studies does not require us, in Professor Nicholson's phrase, "to park [our] common sense at the academy door."118 First, people who are attracted to public office generally do have strong personal views on issues. ${ }^{119}$ Second, there are institutional and political incentives to support

restrictions by a belief known to be erroneous is a sharp departure from traditional First Amendment doctrine. Even in the midst of World War II, the Court did not uphold a law requiring a salute of the U.S. flag, see West Virginia State Bd. of Educ. v. Barnette, 319 U.S. 624 (1943), even though a refusal to salute the flag might have created an appearance of disunity damaging to the U.S. war effort-surely an important government interest. See id. at $640-41$. Allowing the "appearance of comuption" to justify government intrusion on First Amendment liberties essentially allows the majority to justify the suppression of minority rights through its own propaganda.

Third, one of the themes of this Essay is that money has not "corrupted" the system. I know of no way to challenge the "appearance of comuption"-others' subjective perceptions that corruption does exist-other than to make the case that their perceptions are wrong. Cf. Gary C. Jacobson, Campaign Finance and Democratic Control: Comments on Gottlieb and Lowenstein's Papers, 18 HOFSTRA L. REV. 369,377 (1989) ("To the extent that the argument verges on '[corruption is] there even if we can't see it,' it is not ... open to disconfirmation .....). A person swayed by the arguments in this Essay should not much care about the "appearance of corruption."

114. See, e.g., Wertheimer \& Manes, supra note 3, at 1128-40.

115. See MousSALLI, supra note 94, at 6; SORAUF, supra note 18, at 316; Janet Grenzke, PACs and the Congressional Supermarket: The Currency is Complex, 33 AM. J. POL. SCI. I, 1 (1989); Sabato, supra note 107, at 159-62; cf. W.P. Welch, Campaign Contributions and Legislative Voting: Milk Money and Dairy Price Supports, 35 W. POL. Q. 478, 479 (1982) ("[T]he influence of contributions is 'small,' at least relative to the influences of constituency, party, and ideology."). But see Lowenstein, supra note 3 , at 313-22 (arguing that such studies are seriously flawed).

116. Sabato, supra note 107 , at 160 .

117. MOUSSALLI, supra note 94 , at 5-6.

118. Nicholson, supra note 3 , at 464 .

119. This simple observation is often missed by campaign reformers, even those with an otherwise skeptical eye. For example, Sanford Levinson found it "scandalous" that 64 Democrats in the House of Representatives voted for a capital gains tax cut in 1989, writing, "I cannot believe [they] would have voted for this bill . . . if they were not so dependent on campaign contributions from that sector of the population which is most likely to benefit from the bill." Sanford Levinson, Electoral Regulation: Some Comments. 18 HOFSTRA. L. REV. 411,412 n.5 (1989). Though hotly debated, considerable literature suggests that a reduction in capital gains tax rates would actually increase government revenue. See, e.g., George R. Zodrow, Economic Analyses of Capital Gains Taxation: Realizations, Revenues, Efficiency and Equity, 48 TAX L. REV. 419, 429-30 (1993). Perhaps these Democrats believed such arguments, and merely wanted to cut the deficit or raise revenue to fund social programs. 
party positions. These can include logistical and financial support, ${ }^{120}$ appeals to party unity, ${ }^{121}$ pressure regarding committee assignments, ${ }^{122}$ and promises of support from party leaders on future issues. ${ }^{123}$ Third, large campaign contributors are usually offset by equally well-financed interests that contribute to a different group of candidates. In fact, contributors frequently suffer enormous losses in the legislative process, as funds are spent to promote positions that ultimately fail. ${ }^{124}$ Finally, money is not the only political commodity of value. For example, in 1993-94 the National Rifle Association (NRA) contributed nearly $\$ 2$ million to congressional campaigns through its PAC. ${ }^{125}$ However, the NRA also has over three million members, "who focus intently, even solely, on NRA issues in their voting." 126 In many congressional districts, the NRA is capable of "shift[ing] vote totals by close to five percent." ${ }^{27}$ The NRA's power thus would seem to come more from votes than from dollars. However, to the extent that it comes from dollars, that too is related to votes; i.e., it is the group's large membership that yields large amounts of contributions. Groups advocating gun control often complain that the NRA outspends them, but rarely mention that the NRA also outvotes them. ${ }^{128}$

An unwillingness to accept the possibility of legislative defeat (or in this case victory-the capital gains tax cut was defeated) on the merits tends to permeate reformist writing. See, e.g., Wright, supra note 4 , at $618-19$.

120. See David Adamany, Political Finance and the American Political Parties, 10 Hastings CONST. L.Q. 497, 539-41 (1983).

121. See, e.g., Norman J. Ornstein, The Rising Republican Centrists: Congress's New Power Brokers, WASH. POST, Nov. 20, 1995, at C3 (noting that in order to achieve even limited goals, pressure for party unity grows as party's legislative strength declines).

122. See, e.g., Richard Reeves, A Matter of Conscience, BUF. NEWs, Mar. 17, 1995, at B3 (discussing Republican pressure on Senator Mark Hatfeld to give up his seat as Appropriations Committee chairman after voting against balanced budget amendment to U.S. Constitution).

123. See, e.g., Alan McConagha, Inside Politics, WASH. TIMES, Dec. 9, 1993, at A5 (noting that Representative Marjorie Margolies-Mezvinsky cast deciding vote for President Clinton's 1994 budget because President promised to hold conference on entitlements in her district).

124. See SoRAuF, supra note 1 , at 165.

125. The Top PACs of the 1993-94 Election Cycle, POL. FIN. \& LOBBY REP., Apr. 26, 1995, at 3.

126. SORAUF, supra note 1 , at 166.

127. Id.

128. When confronted with a liberal Congress and President in 1993-94, money did not gain the NRA victory over the Brady Bill or the assault weapons ban. However, the election of a new congressional majority in 1994 may result in repeal of both of the aforementioned pieces of legislation.

Of course, the NRA is not a typical group, and is perhaps an unfair example. Professor Lowenstein suggests that many groups lacking the NRA's level of voter support manage to obtain legislative success, suggesting used car dealers, sugar beet growers, and members of the tobacco industry as examples. See Daniel H. Lowenstein, Election Laiv: Cases and Materials, TEacher's Manual 116 (1995). Yet these examples are not so persuasive for the reformers' cause as it might seem. Certainly the tobacco industry can call on large numbers of voters throughout the Upper South, and even in parts of southern Ohio, Indiana, and Maryland, which are home to tobacco growers, processors, pickers, packagers, marketers and more. Behind them stand millions of Americans who enjoy smoking. Over 80.000 used car dealers dot the American landscape, employing tens of thousands of workers. Max Gates, FTC Targets Buyer's Guide Violations, AUTOMOTIVE NEws, Mar. 27. 1995, at 46. Sugar beet growers can be found from Ohio to California and likewise draw on a vast network of employees and suppliers for support. Combined with the domestic com syrup industry, beet growers provide over 420,000 jobs. David Hendee, Defending the Sugar Program. OMAHA WORLD-HERALD. July 17. 1995, at 1. 
If campaign contributions have any meaningful effect on legislative voting behavior, it is on a limited number of votes, generally related to specialized or narrow issues arousing little public interest. ${ }^{129}$ A legislator is unlikely to accept a campaign contribution, which can be used only to attempt to sway voters, in exchange for an unpopular vote, which definitely alienates voters. ${ }^{130}$ Therefore, specialized issues provide the best opportunity to trade votes for money. ${ }^{131}$ On these issues, prior contributions may provide the contributor with access to the legislator or legislative staff. The contributor may then be able to shape legislation to the extent that such efforts are not incompatible with the dominant legislative motives of ideology, party affiliation and agenda, and constituent views. ${ }^{132}$ Whether or not the influence of campaign contributions on these limited issues is good or bad depends on one's views of the resulting legislation. The exclusion of knowledgeable contributors from the legislative process can just as easily lead to poor legislation with unintended consequences as can their inclusion. ${ }^{133}$ In any case, it must be stressed that such issues are few. ${ }^{134}$

The motivation for efforts to limit campaign contributions and spending may not be the belief that money sways votes in the legislature, but the fact that many campaign finance reformers are unhappy with the ideologies and voting tendencies of those being elected to office. ${ }^{135}$ Campaign finance

For an excellent discussion of the complex yet limited relationship between contributors and legislative voting, see SORAUF, supra note 18, at 307-17.

129. SORAUF, supra note 1 , at 166-67; Sabato, supra note 107 , at 160 . Lowenstein argues that the emphasis on floor votes misses the point; the action may take place elsewhere in the legislative process, such as in committee. See Lowenstein, supra note 3, at 313-29; see also Wertheimer \& Manes, supra note 3 , at 1140 ("'[The payback] may not come in a vote."' (quoting former Senator Proxmire)). This would seem to be true at some level. But as Gary Jacobson points out, this argument suffers from the weakness of not being open to disconfirmation. See Jacobson, supra note 113, at 377 . To the extent we have empirical data, however, it appears that the reformers consistently overstate the influence of money on the legislative process.

130. See Strauss, supra note 92 , at $1372-73$.

131. See Sabato, supra note 107 , at 160.

132. See id. at 160-61.

133. See Strauss, supra note 92 , at $1378-79$.

134. See Sabato, supra note 107 , at 160 . Just how many votes are affected is uncertain. Welch's study of dairy price supports, a relatively specialized issue not usually subject to intense public scrutiny, found that the influence of money was dwarfed by party, ideology, and constituent concerns. See Welch, supra note 115 , at 479 .

135. See Lowenstein, supra note 3, at 346-47; see also Wright, supra note 4, at 618-19 (citing congressional resistance to numerous "liberal" causes, including a windfall tax on oil companies, government cost controls on hospitals, environmental legislation, regulation of auto dealers, investment credits, and "any other legislation that affects powerful, organized interests," as evidence of need for campaign finance restrictions).

Of course, campaign finance reform, like most issues, does not always divide along traditional liberal/conservative lines. Many prominent conservatives, such as Barry Goldwater, have supported reform efforts, see Wertheimer \& Manes, supra note 3, at 1127, while liberals such as Professor Martin Shapiro have often remained skeptical, see Martin Shapiro, Corruption, Freedom and Equality in Campaign Financing, 18 HOFSTRA L. REV. 385 (1989). This does not change the basic point that many reformers see the issue in terms of silencing the forces that have defeated cherished legislation. Goldwater, incidentally, would have benefited from limits on contributions, since he, more than most candidates, relied on a large base of small donors. See supra text accompanying note 84 . 
reformers sometimes seem to envision a world in which career officeholders, freed from the corrupting influence of money, lobbyists, and, it might be said, public opinion, would produce good, wise, and fair legislation. This notion of the philosopher-bureaucrat, popular during the Progressive era, has been largely discredited by modern public choice scholarship as an unattainable and, indeed, undesirable ideal. ${ }^{136}$ And although campaign finance reformers have long posed as disinterested citizens seeking only good government, in fact they have often targeted certain types of campaign activities, "at least in part because [those activities] are closely tied to political agendas that reformers oppose." 137 They therefore favor regulation that would tilt the electoral process in favor of preferred candidates. ${ }^{138}$

The available evidence simply does not show a meaningful, causal relationship between campaign contributions and legislative voting patterns. While campaign contributions may influence votes in a few limited cases, this would not seem to justify wholesale regulation.

The pressure for campaign finance regulation has been based on assumptions that are, at best, questionable, and, at worst, seriously flawed. Not surprisingly, then, campaign finance reform efforts enacted into law have had negative consequences for our political system.

\section{THE UNDEMOCRATIC CONSEQUENCES OF CAMPAIGN FINANCE REGULATION}

Campaign finance reform has generally focused on three specific tactics for promoting change: limiting contributions, whether by individuals, corporations, or PACs; limiting campaign spending; and, ultimately, using public funding for campaigns. ${ }^{139}$ These reform tactics have several negative

136. See Gottlieb, supra note 17, at 274-76. For a sampling of work by public choice economists, see, e.g." James M. Buchanan \& Gordon Tullock, THE Calculus of Consent (1962); Randall G. HolCOMBE, AN ECONOMIC ANALYSIS OF DEMOCRACY (1985); DWIGHT R. LEE \& RICHARD B. MCKENZIE, FAILURE AND PRogress (1993); Geoffrey Brennan \& James Buchanan, The Normative Purpose of Economic 'Science': Rediscovery of an Eighteenth Century Method, 1 INT'L REV. L. \& ECON. 155 (1981). The basic insight of public choice theory as applied to government is that government officials, like private individuals, will attempt to maximize personal worth, whether through power, wealth, or some other benefit. Thus, they must be checked by outside interests. See, e.g., RANDALl G. HolcoMBE, PuBLIC POLICY AND THE QUALITY OF LIFE 5-6, 18-20 (1995); DWIGHT R. LEE \& RICHARD B. MCKENZIE, REgulatiNG GOVERNMENT 10-13 (1987).

137. BeVier, supra note 15 , at 1061 .

138. Sanford Levinson, Regulating Campaign Activity: The New Road to Contradiction?, 83 MICH. L. REV. 939, 945 (1985).

139. See, e.g., Lowenstein, supra note 3, at 351-60; Wertheimer \& Manes, supra note 3, at 1131. A fourth legislative tactic, public disclosure of campaign finance information, was included in FECA and most state legislation regulating campaign finance, and may have even broader support. See Sabato, supra note 107, at 171. Even many ardent opponents of campaign finance reform accept the benefits of disclosure laws. See, e.g., MousSALLI, supra note 94, at 20-21. My own view is that disclosure laws raise serious First Amendment questions, and thus are not free from difficulties. See Bradley A. Smith, Congress Shall Make No Law . . . WASH. TIMES, Dec. 29, 1994, at A19. Because disclosure laws do not have the same 
consequences, which can be broadly labeled "undemocratic." Specifically, campaign finance reform efforts entrench the status quo; make the electoral system less responsive to popular opinion; strengthen the power of select elites; favor wealthy individuals; and limit opportunities for "grassroots" political activity. ${ }^{140}$ This part discusses each of these consequences in turn, assuming that any regulation exists within a system of private campaign funding. A discussion of the consequences of public funding follows in Part V.

\section{A. Campaign Finance Reform Entrenches the Status Quo}

Campaign finance reform measures, in particular limits on contributions and overall spending, ${ }^{141}$ insulate the political system from challenge by outsiders, and hinder the ability of challengers to compete on equal terms with those already in power.

Contribution limits tend to favor incumbents by making it harder for challengers to raise money and thereby make credible runs for office. ${ }^{142}$ The lower the contribution limit, the more difficult it becomes for a candidate to raise money quickly from a small number of dedicated supporters. The consequent need to raise campaign cash from a large number of small contributors benefits those candidates who have in place a database of past contributors, an intact campaign organization, and the ability to raise funds on an ongoing basis from PACs. ${ }^{143}$ This latter group consists almost entirely of current officeholders. Thus, contribution limits hit political newcomers

type of broadly "undemocratic" consequences as the other major tactical goals of the reform movement. this Essay does not address them.

140. Supporters of heavy campaign finance regulation argue that the failure of the 1974 FECA Amendments, and specifically FECA's contribution and expenditure limits, to solve the alleged evils of the current system is due to the unwarranted constitutional restrictions placed on their efforts by Buckley v. Valeo, 424 U.S. 1 (1976) (per curiam). See, e.g., Kirk J. Nahra, Political Parties and the Campaign Finance Laws: Dilemmas, Concerns and Opportunities, 56 FORDHAM L. REV. 53, 55 (1991); see also John S. Shockley, Money in Politics: Judicial Roadblocks to Campaign Finance Reform, 10 HASTINGS CoNST. L.Q. 679, 714-15 (1983). This Essay demonstrates, however, that regardless of Buckley, the fundamental assumptions of the reform effort are incorrect. The criticisms that follow do not depend on the current constitutional regime: They would apply to FECA as originally enacted, and, to varying degrees, to the various reformist schemes proposed in the post-Buckley world. A public policy based on flawed assumptions is unlikely to be successfu! no matter how enacted.

Furthermore, the Court has not retreated from Buckley's basic holdings, and thus reformist efforts must take the constraints of Buckley into account.

141. Limits on campaign contributions are allowed under the Buckley framework, have been enacted into federal law, and are included in virtually every reformist-scholar proposal. See, e.g., Lowenstein, supra note 3, at 357 (recommending limiting contributions to just $\$ 100$ ); Nicholson, supra note 3, at 471; Raskin \& Bonifaz, supra note 52, at 1191; Wertheimer \& Manes, supra note 3, at 1155. Though mandatory limits on overall spending levels are not allowed under Buckley, voluntary limits linked to the disbursement of public funds are permitted, see Buckley, 424 U.S. at 85-108. For an excellent discussion of the Court's decision on this point, see Marlene A. Nicholson, Political Campaign Expenditure Limitations and the Unconstitutional Condition Doctrine, 10 HASTINGS CONST. L.Q. 601 (1983).

142. Malbin, supra note 87 , at 9.

143. See Colloquia, Constitutional Implications of Campaign Finance Reform, 8 ADMIN. L.J. AM. U. 161,169 (1994) (comments of Robert Peck). 
especially hard because of the difficulties candidates with low name recognition have in raising substantial sums of money from small contributors.

Even well-known public figures challenging the status quo have traditionally relied on a small number of wealthy patrons to fund their campaigns. For example, Theodore Roosevelt's 1912 Bull Moose campaign was funded almost entirely by a handful of wealthy supporters. ${ }^{144}$ Senator Eugene McCarthy's 1968 antiwar campaign relied for seed money on a handful of six-figure donors, including Stewart Mott, who gave approximately $\$ 210,000$, and Wall Street banker Jack Dreyfus, Jr., who may have contributed as much as $\$ 500,000 .{ }^{145}$ John Anderson would probably have had more success in his independent campaign for the Presidency in 1980 had his wealthy patron, the ubiquitous Mr. Mott, been able to contribute unlimited amounts to his campaign. ${ }^{146}$ And whereas Ross Perot's 1992 campaign was made possible by the Supreme Court's holding in Buckley that an individual may spend unlimited sums to advance his own candidacy, the contribution limits upheld in Buckley would make it illegal for Perot to bankroll the campaign of a more plausible challenger in 1996, such as Colin Powell or Bill Bradley. ${ }^{147}$ Despite recent polls showing strong voter interest in a third-party or independent candidate for President in 1996, contribution limits make a serious independent challenge virtually impossible, unless Mr. Perot himself, or someone of comparable wealth, is again the candidate.

Beyond making it harder for challengers to raise cash, contribution limits also tend to decrease overall spending, ${ }^{148}$ which further works against challengers. Incumbents begin each campaign with significant advantages in name recognition. ${ }^{149}$ They are able to attract press coverage because of their office, and they often receive assistance from their staffs and send constituents postage-free mailings using their franking privilege. ${ }^{150}$ Through patronage

144. See ThAYER, supra note 22 , at 55 .

145. See Deposition of Eugene McCarthy, Ex. C at 50, Buckley v. Valeo, 519 F.2d 821 (D.C. Cir. 1975) (No. 75-1061), aff'd in part and rev'd in part, 424 U.S. 1 (1976) (per curiam); Deposition of Stewart R. Mott, Ex. D at II 11, Buckley, 519 F.2d 821 (No. 75-1061) [hereinafter Statement of Stewart R. Mott].

146. See generally Stewart R. Mott, Independent Fundraising for an Independent Candidate, 10 N.Y.U. Rev. L. \& SOC. ChaNGE 135, 138-41 (1981).

147. More recently, millionaire Malcolm S. Forbes, Jr., a political neophyte, declared his intention to seek the Republican presidential nomination in 1996. Forbes indicated that he would not have sought the nomination had former Congressman and Secretary of Housing and Urban Development Jack Kemp decided to run. Martha T. Moore, Main Goal: Carry Banner of Supply Side Economics, USA TODAY, Sept. 6, 1995, at 4B. Kemp chose not to run in part because he did not want to engage in fund-raising. Alan Elsner, Running for the White House Will Take Megabucks This Time, S.F. CHRON., Feb. 1, 1995, at A9. Were Forbes able to donate to Kemp the $\$ 25$ million he planned to spend on his own campaign, Kemp might have run and would quite likely have been a front-runner for the Republican nomination.

148. Lowenstein, supra note 63 , at $399-401$. This is because a candidate's spending is limited to available funds. By making it harder to raise money, contribution limits will indirectly lower overall spending levels. Id.

149. Gottlieb, supra note 17 , at 224 .

150. $I d$. 
and constituent favors, they can further add to their support. ${ }^{151}$ One way for challengers to offset these advantages is to spend money to make their names and positions known. Those few studies that have attempted to isolate and quantify the effect of campaign spending on votes have found that, once a candidate spends the minimal amount needed to penetrate the public consciousness, additional spending affects a very limited number of votes. ${ }^{152}$ However, the positive effect of added spending is significantly greater for challengers than for incumbents. ${ }^{153}$ In fact, studies show an inverse relationship between high levels of incumbent spending and incumbent success. Heavy spending by an incumbent indicates that the incumbent is in electoral trouble and facing a well-financed challenger. ${ }^{154}$ Because an incumbent's added spending is likely to have less of an effect on vote totals than the additional spending of a challenger, limits on total campaign spending will hurt challengers more than incumbents. By lowering overall campaign spending, therefore, contribution limits further lock into place the advantages of incumbency and disproportionately harm challengers.

Absolute spending ceilings, whether "mandatory" or "voluntary," have the potential to exacerbate this problem considerably. ${ }^{155}$ Set low enough, they may make it impossible for challengers to attain the critical threshold at which they can reach enough voters to run a credible race. ${ }^{156}$ Overall spending caps also prevent challengers from ever spending more than incumbents. While spending more than one's opponent is not necessary to win an election, ${ }^{157}$

\section{Id.}

152. See JACOBSON, supra note 108 , at 54.

153. Id. at 50,53; Jacobson, supra note 94 , at $62-63$ (finding that challengers gained approximately 3.5 percentage points for each $\$ 100,000$ spent, while incumbent vote totals actually went down with higher spending). This would appear to be because the incumbents are better known to the constituency at the start of the campaign. The advantages they gain from holding office can be viewed as money already spent in a campaign, and indeed often reflect past campaign spending. See John R. Lott, Jr., Explaining Challengers' Campaign Expenditures: The Importance of Sunk Nontransferable Brand Name, 17 PUB. FIN. Q. 108 (1989). As such, incumbents will reach a point of diminishing marginal returns sooner than challengers, with better-known and longer-serving incumbents reaching that point sooner than lesser-known and shortterm incumbents. Anecdotal evidence from the 1994 elections would seem to support this last point. The three incumbents who lost despite spending at least $\$ 1$ million more than their challengers were three of the best-known, longest-serving incumbents in Congress: Dan Rostenkowski, Thomas Foley, and Jack Brooks. See Money in House Seat Turnovers, POL. FiN. \& LOBBY REP., Nov. 23, 1994, at 3, 4.

154. JACOBSON, supra note 108 , at 53.

155. Mandatory spending ceilings are not allowed under Buckley, but voluntary ceilings created by offering public subsidies to candidates who agree to abide by the ceiling are a common feature of many reform proposals. See Nicholson, supra note 3, at 473-75; Wertheimer \& Manes, supra note 3, at 1149-54. Many of these "voluntary" proposals would be prime candidates to be struck down by the Supreme Court as violating the "unconstitutional conditions" doctrine. Typically, they are so punitive toward candidates who do not opt into the system that voluntary limits are, in effect, mandatory. See, e.g., U.S. CONGRESS ASSESSMENT PROJECT, THE HERITAGE Foundation, AdVANTAGE INCUMBENTS: ClinTon's CAMPAIGN FINANCE PROPOSAL 11 (1993) [hereinafter ADVANTAGE INCUMBENTS] (discussing reform bill proposed by President Clinton in 1993).

156. Incumbent lawmakers will always have powerful personal incentives to set spending caps at a level that disadvantages their challengers. See, e.g., ADVANTAGE INCUMBENTS, supra note 155, at 9-10: Lowenstein, supra note 3 , at 335 .

157. See discussion supra Section III.C. 
a challenger's ability to outspend an incumbent can help to offset the advantages of incumbency. ${ }^{158}$ Efforts to limit spending, whether mandatory or through incentive-based "voluntary" caps, should therefore not be viewed as benign or neutral.

\section{B. Campaign Finance Reform Promotes Influence Peddling and Reduces Accountability}

Limits on contributions increase the incentives for contributors to seek "influence" rather than the election of like-minded legislators, and reduce the effectiveness of legislative-monitoring efforts. We have previously seen that, though the argument is overstated, campaign contributions may affect legislative votes on a limited number of issues. ${ }^{159}$ Many reformers have been more concerned about contributors who adopt a "legislative" strategy, attempting to influence legislative votes, than with donors who adopt an "electoral" strategy, aimed at influencing election outcomes. ${ }^{160}$ Yet strangely enough, contribution limits, the most popular reform measure, encourage PACs and other monied interests to adopt legislative strategies. This results in the representative system being less responsive to public opinion.

Campaign contributors must weigh the costs and benefits of pursuing an electoral strategy versus a legislative strategy. Money given to a losing challenger is not merely money wasted, it is money spent counterproductively, as it will probably increase the enmity of, and decrease access to, the incumbent. With incumbents winning in excess of $90 \%$ of House races, an electoral strategy of supporting challengers has very high risks. Even in close races, so long as a contributor is limited to a maximum contribution of $\$ 10,000$ (or some other amount), ${ }^{161}$ the contributor's campaign donation is unlikely to increase significantly the odds of a victory for the challenger. The low-risk alternative is to contribute to incumbents in the hope that a legislative strategy

158. Sabato, supra note 107 , at 169 . Incumbency is already the single best predictor of electoral success. Limits on campaign financing, by handicapping challengers still further, tend to add to political ossification. Though rates of success of incumbents seeking reelection have been consistently above $75 \%$ since the turn of the century, these rates have risen to record heights in this era of extensive campaign finance regulation. See JOHN H. FUND, TERM LIMITATION: AN IDEA WhOSE TIME HAS COME 5 tbl. 2 (1990). Even in the 1994 elections, which resulted in significant political realignment, $91.4 \%$ of congressional incumbents seeking reelection were victorious. See Edward Zuckerman, Money Didn't Matter for Most Challengers Who Won, POL. FIN. \& LOBBY REP., Nov. 23, 1994, at 1, I. The Republican gains came primarily from the GOP's near sweep of "open" seats, i.e., seats in which the incumbent did not seek reelection. While money can help to "buy" votes, it "buys" far more votes for challengers than for incumbents. This being the case, money is an equalizer in the system, helping challengers to overcome the tremendous advantages of incumbency. Ruy A. Teixeira, Campaign Reform, Political Competition, and Citizen Participation, in RETHINKING POLITICAL REFORM: BEYOND SPENDING AND TERM LIMITS 5, 10-11 (Ruy A. Teixeira et al. eds., 1994).

159. See discussion supra Section III.D.

160. See supra note 92 .

161. This is the maximum contribution for a PAC making a donation in both the primary and general election under FECA. See 2 U.S.C. § 441(a) (1988). 
might succeed, at least by minimizing otherwise hostile treatment aimed at the contributor's interests. ${ }^{162}$ Thus, because the risk of an electoral strategy is so high, contribution limits tend to lock the rational contributor into a legislative strategy. ${ }^{163}$ To the extent, then, that campaign contributions influence legislative voting behavior, campaign finance regulation in the form of contribution limits is likely to make the problem worse. ${ }^{164}$

Professor Lowenstein attempts to get around this problem by setting the contribution threshold at $\$ 100$, a level so low that a legislative strategy would have no real chance of success. ${ }^{165}$ This would effectively abolish private funding of political campaigns. ${ }^{166}$ As a practical matter, then, public funding would have to take over the system, ${ }^{167}$ with the attendant problems I will shortly address. Even if public funding could be successfully implemented, however, squeezing out private money would in other ways make the political system less responsive.

PACs perform a valuable monitoring function in the current campaign regime, a function that would be lost were private funding to be eliminated. It has been suggested that the real issue that the campaign reform movement attempts to address is "shirking," or the tendency of elected officials to betray their public trust in favor of their own or other interests. ${ }^{168}$ In most cases, it will not be rational for individuals to devote considerable time to monitoring the performance of elected officials. However, by banding together with others having similar concerns, individuals can perform the monitoring function at a reasonable cost. Interest groups, and the PACs they spawn, thus play an important role in monitoring officeholders' performances so as to prevent shirking. ${ }^{169}$ Therefore, measures that would limit or eliminate the role of PACs are likely to reduce legislative monitoring, leading to a legislature ever more isolated from the people.

162. See Lowenstein, supra note 3, at 308-13, for a general discussion of the strategy considerations facing donors.

163. It may be worthwhile to consider the proposition that PACs have less of a corrupting influence on incumbent legislators than those legislators have on PACs. See Strauss, supra note 92, at 1380-82 (arguing that incumbent lawmakers may use threat of adverse legislative action to "extort" contributions from political contributors).

164. This does not mean that large contributors, even PACs, never give to challengers. They may gamble that a challenger can be the exception who wins, or they may be motivated purely by ideology. But to the extent they hope to see a difference as a result of their contributions, a legislative strategy will almost always make more sense.

165. See Lowenstein, supra note 3, at 357. At a maximum contribution of just $\$ 100$, it is hard to see a legislator being swayed by any single contribution. Note, however, that this would make bundling of contributions and independent spending, two other villains in the reformist literature, more valuable.

166. See Jacobson, supra note 82 , at $610-11$. It is worth noting that private funding has many advantages: It is easy to administer; it supports traditional American values of volunteerism; it avoids First Amendment problems; and it actively involves millions of Americans in the political process far more than does a government check-off. See Sorauf, supra note 5, at 1361.

167. See Lowenstein, supra note 3 , at 350 .

168. See Jacobson, supra note 113, at 370.

169. BeVier, supra note 89 , at 1273-76. 
Finally, there is always the possibility that limiting private contributions will simply increase the value of a more corrupting alternative: outright bribery. ${ }^{170}$ It is naive to think that when the government is heavily involved in virtually every aspect of economic life in the country (and quite a few noneconomic spheres as well), people affected by government actions will accept whatever comes without some kind of counterstrategy. ${ }^{171}$ In this way, too, contribution limits may make the electoral system less responsive to public opinion and, therefore, less democratic.

\section{Campaign Finance Regulation Favors Select Elites}

Campaign finance reform is usually sold as a populist means to strengthen the power of "ordinary" citizens against dominant, big-money interests. ${ }^{172}$ In fact, campaign finance reform has favored select elites and further isolated individuals from the political process.

There are a great many sources of political influence. These include direct personal attributes, such as speaking and writing ability, good looks, personality, time and energy, and organizational skills, as well as acquired attributes, such as wealth, celebrity, and access to or control of the popular press. In any society, numerous individuals will rise to the top of their professions to become part of an "elite." Both as a prerequisite to their success and as a reward for it, such individuals will have certain abilities that they can use for political ends. For example, Hollywood celebrities, by virtue of their fame, may gain audiences for their political views that they would not otherwise obtain. They may be invited to testify before Congress, despite their lack of any particular expertise, ${ }^{173}$ or they may use their celebrity to assist campaigns through appearances at rallies. ${ }^{174}$ Similarly, successful academics may write powerful articles that change the way people think about issues. Labor organizers may have at their disposal a vast supply of human resources that they can use to support favored candidates. Media editors, reporters, and anchors can shape not only the manner, but also the content, of news reporting. Those with marketing skills can apply their abilities to raise funds or to produce advertising for a candidate or cause. Successful entrepreneurs may amass large sums of money that they can use for political purposes. ${ }^{175}$

170. Professor Nicholson is right when she argues that the cost of illegal bribery is so high that most influence seekers and peddlers will not attempt it. See Nicholson, supra note 3, at 466-68. Nevertheless, influence seekers denied a lawful means to press their case will be more prone to consider unlawful means, and there will always be takers at the right price.

171. BeVier, supra note 89 , at 1276.

172. Sorauf, sipra note 5 , at 1356.

173. See, e.g., Celebrity Hearings: Much Show, Little Go, SAN ANTONIO EXPRESS-News, July 1I, 1994, available at 1994 WL 3558496 (noting that Meryl Streep and Steven Spielberg both admitted their lack of relevant knowledge during their testimony before congressional committees).

174. See Nina Easton, Star Trek: Hollywood on the Stump. L.A. TIMES. Oct. 11, 1988, at 1.

175. As may most others on this list, especially celebrities. 
The regulation of campaign contributions and spending limits the political employment of immediately available wealth but not any of these other attributes. $^{176}$ As an initial matter, there is no serious reason why the successful entrepreneur should not be able to transfer her talents at creating wealth to the political arena, while the successful marketer or political organizer is permitted to do so. ${ }^{177}$ There is no a priori reason why a person with a flair for political organizing should be allowed political influence that is denied to the person with a flair for manufacturing.

The common response to this argument is that money can buy other sources of power: It can purchase labor, marketing know-how, media access, even speaking coaches and improved physical appearance. ${ }^{178}$ Not only does this response not justify the prejudice against money, ${ }^{179}$ however, but it is simply incorrect, insofar as it sees this as a unique feature of money. A winning personality, the ability to forge political alliances, and the time to devote to politics can, like money, be used to gain access to the media, labor, and other prerequisites to political success. Moreover, these skills, like the ability to produce moving television ads or to write effective campaign literature and speeches, are themselves convertible into money. For example, money can be raised through slick direct mail pitches, operation of phone banks, advertisements, speeches at rallies, booths at county fairs, and countless other means. The trick to effective electoral politics is to take the assets with which one begins and to use them to obtain additional assets that one lacks. Money is no different. ${ }^{\mathrm{I} 00}$

Once we accept the fact that different individuals control different sources of political power, it becomes apparent that attempts to exclude a particular form of power-money - from politics only strengthen the position of those whose power comes from other, nonmonetary, sources, such as time or media access. For example, though the Supreme Court has allowed states to limit even independent expenditures by nonmedia corporations in candidate races, ${ }^{181}$ newspapers, magazines, and TV and radio corporations can spend unlimited sums to promote the election of favored candidates. Thus, Donald Graham, the publisher of the Washington Post, has at his disposal the

176. BeVier, supra note 89 , at 1268 .

177. Id.

178. David W. Adamany \& George E. Agree, Political Money 3 (1975).

179. See BeVier, supra note 89 , at 1268 .

180. As of October 1995, Senator Phil Gramm appeared to be able to convert his fund-raising skills into a substantial campaign fund, but having gone that far, he seemed unable to use those campaign funds to acquire other assets needed in his campaign for President. See Paul West, Pryor's Retirement Heurtens '96 GOP Hopefuls, CHI. SUN-TIMES, Apr. 23, 1995, at 24. Conversely, there are numerous examples of candidates beginning with little money who are able to capitalize on other attributes to raise campaign cash. One example is President Bill Clinton, who began his 1992 presidential campaign with little cash. See Jack W. Germond \& Jules Witcover, Money is Tight for the Democratic Six, 23 NAT"L J. 2984, 2984 (1991).

181. Austin v. Michigan State Chamber of Commence, 494 U.S. 652 (1990). For further discussion of media influence, see Levinson, supra note 119, at 412-13. 
resources of a media empire to promote his views, free from the campaign finance restrictions to which others are subjected. $A B C$ News anchor Peter Jennings is given a nightly forum on national television in which to express his views. ${ }^{182}$

Media elites are not the only group whose influence is increased by campaign spending and contribution limits. Restricting the flow of money into campaigns also increases the relative importance of in-kind contributions and so favors those who are able to control large blocks of human resources. Limiting contributions and expenditures does not particularly democratize the process, but merely shifts power from those whose primary contribution is money to those whose primary contribution is time, organization, or some other resource-for example, from small business groups to large labor unions. Others who benefit from campaign finance limitations include political middlemen, public relations firms conducting "voter education" programs, lobbyists, PACs such as EMILY's List that "bundle" large numbers of $\$ 1000$ contributions, ${ }^{183}$ and political activists. ${ }^{184}$ These individuals and groups may or may not be more representative of public opinion than the wealthy philanthropists and industrialists who financed so many past campaigns.

In theory, it may be possible to limit in-kind contributions in the same manner as monetary contributions. ${ }^{185}$ In practice, however, such an effort raises almost insurmountable administrative difficulties and, in the end, would not solve the unequal treatment created by the prejudice against money. Consider, for example, a politically talented, twenty-five-year-old Harvard law student from a privileged background, who chooses to volunteer on a presidential campaign during summer break, passing up a law firm clerkship paying $\$ 15,000$ for the summer. Consider, at the same time, a West Virginia high school dropout who goes to work in a body shop at age seventeen, scrapes together some money to launch his own shop at age twenty-two, opens a second shop two years later, and then at age twenty-five, angered over government policies affecting his business, seeks to promote political change

182. Surveys have indicated that the views of joumalists often differ sharply from those of the public at large. See Stanley Meisler, Public Found to be More Cynical Than Press, L.A. TIMes, May 22, 1995, at All (noting that only $5 \%$ of journalists, versus $39 \%$ of the public, describe themselves as politically "conservative"). For an ex-journalist's view of this power, see Jonathan Rowe, The View of You from the Hill, COLUM. JOURNALISM REV., July 1994, at 47.

183. "Bundling" is a practice in which a PAC solicits its supporters for contributions not only to the PAC itself, but directly to the candidates. The PAC collects those campaign donations, "bundles" them together, and delivers them to the candidate on behalf of the individual donors.

184. See, e.g., Money in Politics, 10 Hastings CONST. L.Q. 466, 486 (1983) (providing comments of Herbert Alexander).

185. Several proposals to limit in-kind contributions have been made. See, e.g., Carville B. Collins, Maryland Campaign Finance Law: A Proposal for Reform, 47 MD. L. REV. 524, $544-46$ (1988); Wertheimer \& Manes, supra note 3, at 1557-58. For a more theoretical discussion of the administrative problems involved with limiting in-kind contributions, see Edward B. Foley, Equal-Dollars-Per-Voter: $A$ Constitutional Principle of Campaign Finance, 94 COLUM. L. REV. 1204. 1246-49 (1994). Reformist scholars, however, choose almost exclusively to target the influence of money. 
by contributing $\$ 15,000$ to a political campaign. Each individual seeks to forego $\$ 15,000$ in consumption to promote his political beliefs, but only the activities of the Harvard law student are legal. ${ }^{186}$ As this simple illustration shows, truly limiting the comparative advantages of in-kind contributions is simply not possible. How, for example, would we limit the ability of Arnold Schwarzenegger to turn his celebrity into Republican votes in any manner compatible with the First Amendment? Could we order Republican media whiz Roger Ailes to divide his time evenly between Democratic and Republican candidates? Prohibit Meryl Streep from giving congressional testimony? Order Jesse Jackson to cease his voter registration campaigns, which are clearly aimed at registering more probable Democratic than Republican voters? ${ }^{187}$ The question is whether people will be allowed to convert their varied talents into political influence. Efforts to limit the flow of cash exclude from the process those whose talents do not directly lend themselves to political purposes, thereby increasing the relative power of those whose talents are directly applicable to the political arena.

Moreover, the way in which campaign finance regulation favors certain elites raises First Amendment concerns. Traditional First Amendment jurisprudence requires most speech restrictions to be content-neutral, i.e., not to favor any particular viewpoint. ${ }^{188}$ Even those critical of Buckley $v$. Valeo have recognized that content-neutrality is necessary to uphold campaign finance legislation. ${ }^{189}$ Many reformers, however, usually political liberals, view campaign finance reform favorably precisely because they assume that the targeted power base of money works mainly to the advantage of their political opponents. ${ }^{190}$ Once it is conceded that legislation is intended to hamper the expression of some ideas and not others, it is difficult to assert that the regulation is content-neutral.

Favoring nonmonetary elites is also problematic in light of the reformers' goal of achieving political equality. The targeting of a single source of political power, money, does not necessarily make the system more responsive to the interests of the middle and working classes. It is a serious mistake to assume that all members of any one elite group, be it journalists, academics, celebrities, or businesspeople, think alike. As Professor Lillian BeVier points out, such an assumption rests on a group mentality and, at least where money

186. Looked at from the campaign's point of view, one might argue that the law student's real contribution is only what it would cost the campaign to hire someone else to do the same job. The hypothetical remains the same, of course, if the body shop owner's contribution is merely reduced to this amount.

187. A full discussion of the relationship between money and political equality is beyond the scope of this Essay. For a detailed discussion of the issue, see Bradley A. Smith, Money Talks: Speech, Money, and Political Equality (unpublished manuscript in progress, on file with author).

188. LAURENCE H. TRIBE, AMERICAN CONSTITUTIONAL LAW $\S 12-3$, at 798 (2d ed. 1988).

189. See, e.g., Levinson, supra note 138, at 943 (describing views of John Rawls).

190. See supra note 135 and accompanying text. 
is concerned, relies on a rather callow and unsubstantiated notion of a society irretrievably divided between some group known as the "rich," all having similar views and interests, and another group, the "poor," who share a different set of common views and interests. ${ }^{191}$

However, to the extent that differing opinions on issues may be generally held within different elites, the ordinary public is best served by allowing for the interplay among those elites, rather than attempting to exclude a single elite. ${ }^{192}$ Efforts to ensure "equality" of inputs to the campaign process are less likely to guarantee popular control than is the presence of multiple sources of political power. ${ }^{193}$ By decreasing the number of voices in the political debate, a strategy of silencing one source of influence increases the power of groups whose forms of contribution remain unregulated. By creating added instability and a decentralization of power, the interplay of numerous elites may increase opportunities for traditionally less empowered groups to obtain influence. ${ }^{194}$

\section{Campaign Finance Limitations Favor Wealthy Candidates}

Though campaign finance restrictions aim to reduce the role of money in politics, they have helped to renew the phenomenon of the "millionaire candidate"-with Michael Huffington and Ross Perot as only the most celebrated recent examples. ${ }^{195}$ In the Buckley decision, the Supreme Court held that Congress could not limit the amount that a candidate could spend on his or her own campaign. Contribution limits, however, force candidates to raise funds from the public only in small amounts. The ability to spend unlimited amounts, coupled with restrictions on raising outside money, favors those candidates who can contribute large sums to their own campaigns from personal assets. A Michael Huffington, Herb Kohl, or Jay Rockefeller becomes a particularly viable candidate precisely because personal wealth provides a direct campaign advantage that cannot be offset by a large contributor to the opposing candidate. ${ }^{196}$ These candidates represent an array of views across

191. BeVier, supra note 89 , at $1268-69$.

192. See generally Gottlieb, supra note 17, at 271-72 (arguing that presence of fewer power bases fosters tendency towards "oligarchy," which can be offset by "multiple sources of power"). At the risk of being accused of gratuitously hauling out the heavy artillery of political discourse, see also THE FEDERALIST No. 10 (James Madison) (discussing control of faction by interplay).

193. See Gottlieb, supra note 17, at 271 (citing POWER, INEQUality AND DEMOCRATIC Politics 7 (Ian Shapiro \& Grant Reeher eds., 1988)).

194. See id. at 272.

195. Burke, supra note 63, at 357 (noting that over half of U.S. Senators are millionaires).

196. In 1994, Huffington spent approximately $\$ 24$ million of his own fortune to run for the U.S. Senate. High-cost Campaigns, supra note 86, at 8A. By September 30, 1994, Kohl had contributed almost $\$ 4$ million to his 1994 reelection effort. Edward Kennedy and Mitt Romney each loaned or contributed \$2 million to their campaigns for U.S. Senate in Massachusetts. Senate Candidates Add \$3 I.5 Million to Their Own Election Campaigns, POL. FIN. \& LoBby ReP., Oct. 26, 1994, at 1, 3. Physician Bill Frist of Tennessee (\$3.75 million) was another big spender. See Edward Roeder, Big Money Won the Day Last 
the political spectrum. The point is not that these "rich" candidates hold uniform views but, more simply, that a system favoring personal wealth in candidates will restrict the number of viable candidates, potentially limiting voter choice. While most reformers have criticized Buckley for creating precisely this situation, it seems a mistake to exacerbate the problem through added regulation as long as Buckley remains law.

At the same time that contribution limits help independently wealthy candidates, they may harm working-class political interests. Historically, candidates with large constituencies among the poor and the working class have obtained their campaign funds from a small base of wealthy donors. ${ }^{197}$ By limiting the ability of wealthy individuals such as Stewart Mott to finance these efforts, regulations may harm working-class constituencies. Supporters of these candidates simply do not have the funds to compete with other constituencies and candidates. As Stephen Gottlieb has pointed out, "candidates with many supporters who can afford to give the legal limit may be relatively unscathed by 'reform' legislation. As a consequence, it appears that national campaign 'reform' legislation has benefitted the wealthy at the expense of the working class." "198

\section{E. Campaign Finance Regulation Favors Special Interests over Grassroots Activity}

Campaign finance regulation is also undemocratic in that it favors wellorganized special interests over grassroots political activity. ${ }^{199}$ Limitations on contributions and spending, by definition, require significant regulation of the campaign process, including substantial reporting requirements as to the amounts spent and the sources of funds. Typically, regulation favors those

November, Plain DEALER, Dec. 25, 1994, at 1-C. On the House side, Republican Gene Fontenot ( $\$ 2$ million) and Democrat Robert Schuster ( $\$ 1.1$ million) provided much of their own campaign financing. Edward Zuckerman, Money Didn't Matter for Most Challengers Who Won, POL. FIN. \& LOBBY REP., Nov. 23,1994 , at 1,4 .

197. Gottlieb, supra note 17 , at $220-21$.

198. Id. at 221 (footnote omitted). It is worth noting that this dynamic would exist, albeit to a lesser extent, even at Lowenstein's suggested $\$ 100$ contribution limit.

199. See id. at $225 \mathrm{n} .61$, and sources cited therein.

Of course, one person's "special interest" is another's "grassroots lobby," and vice versa. By "special interest," I mean a person or group seeking to influence legislation and government policy, usually in pursuit of a narrowly defined economic interest, typically employing professional staff, and usually having a strong, top-down leadership structure. Such a group is usually more concerned with influencing legislative than public opinion. By a "grassroots lobby," I mean a group that tends to operate outside of traditional centers of political leadership, that typically relies more heavily on volunteer help and a decentralized structure, and that is more likely to be ideologically motivated, even if focused on a narrow issue. Such a group would be somewhat more populist and would usually aim not to influence legislative opinion directly so much as to influence public opinion and awareness and make public opinion known to legislators. I recognize that these definitions are far from precise. The point is that campaign finance regulation leads to a professionalization of politics that may alienate more typical voters and hinder local. volunteer, and unorganized or less organized activity. In discussing "grassroots activity" in this section, I refer to political activity other than the giving of money. 
already familiar with the regulatory machinery and those with the money and sophistication to hire the lawyers, accountants, and lobbyists needed to comply with complex filing requirements. ${ }^{200}$ Such regulation will naturally disadvantage newcomers to the political arena, especially those who are themselves less educated or less able to pay for professional services. Efforts to regulate campaigns in favor of small contributors thus have the perverse effect of professionalizing politics and distancing the system from "ordinary" citizens.

Regulation also creates opportunities to gain an advantage over an opponent through use of the regulatory process, and litigation has now become "a major campaign tactic." 201 Again, one can expect such tactics to be used most often by those already familiar with the rules. Indeed, there is some evidence that campaign enforcement actions are disproportionately directed at challengers, who are less likely to have staff familiar with the intricacies of campaign finance regulation. ${ }^{202}$

Perhaps those most likely to run afoul of campaign finance laws, and thus to be vulnerable to legal manipulations aimed at driving them from the political debate, are unaffiliated individuals engaged in true grassroots activities. For example, in 1991, the Los Angeles Times found that sixty-two individuals had violated FECA contribution limits by making total contributions of more than $\$ 25,000$ to candidates in the 1990 elections. ${ }^{203}$ As the Times noted, while many of these sixty-two were "[s]uccessful business people" who "usually have the benefit of expert legal advice on the intricacies of federal election laws," the next largest group of violators consisted of "[e]Iderly persons ... with little grasp of the federal campaign laws."204 Threats of prosecution have, in fact, been used in efforts to silence dissent from those without "the benefit of expert legal advice on the intricacies of federal election laws."205

200. See Mott, supra note 146 , at 135.

Although the necessary legal expertise can be bought, the cost will often be higher for candidates and groups with no prior experience. In local races, funds may not be available to counter the expertise gained by incumbents through experience. And, of course, it would seem to cut against the grain of the entire reformist effort to increase the importance of specialized legal skills, not to mention the availability of funds to pay for those skills, in determining who wins a campaign.

201. MOUSSALLI, supra note 94 , at 9.

202. See, e.g., Amicus Brief of American Civil Liberties Union of Ohio Foundation, Inc. at 12-14, Pestrak v. Ohio Elections Comm'n, 926 F.2d 573 (6th Cir.) (Nos. 88-3131 \& 88-3132), cert. dismissed, 502 U.S. 1022 (1991) (noting that Ohio Election Code has been enforced almost exclusively against challengers).

203. See Sara Fritz \& Dwight Morris, Federal Election Panel Not Enforcing Limit on Campaign Donations, L.A. TiMES, Sept. 15, 1991, at Al, A8-A9.

204. Id. at Al, A8-A9.

205. Id. at A9. In McIntyre v. Ohio Elections Commission, 115 S. Ct. 1511 (1995), Margaret McIntyre, an Ohio housewife, was fined by the Ohio Elections Commission for the peaceful distribution of truthful campaign literature outside a public meeting. Ms. McIntyre was distributing flyers in opposition to a school tax levy and had signed her brochures simply, "Concerned Parents and Tax Payers." An assistant school superintendent first threatened McIntyre and later brought charges against her for violating an Ohio law prohibiting the distribution of anonymous campaign literature. Only after seven years of 
Even sophisticated interest groups have found campaign finance laws to be a substantial hindrance to grassroots campaign activity and voter education efforts. In 1994, for example, both the U.S. Chamber of Commerce and the American Medical Association (AMA) decided not to publish and distribute candidate endorsements to thousands of their dues-paying members, in response to threats of litigation from the Federal Election Commission (FEC). Under FEC regulations, only sixty-three of the Chamber's 220,000 dues-paying members qualified as "members" for the purposes of receiving the organization's political communications. Similarly, the FEC had held that it would be unlawful for the AMA to distribute endorsements to some 44,500 of its dues-paying members. One AMA lawyer noted that, under the circumstances, communicating endorsements to its dues-paying members was not "worth the legal risk.",206

Campaign finance regulation has been packaged as a means of returning power to "ordinary people." In truth, however, such regulation acts to exclude ordinary people from the political process in a variety of ways: It insulates incumbents from the voting public, in both the electoral and legislative spheres; it increases the ability of certain elites to dominate the debate by eliminating competing voices; it places a renewed premium on personal wealth in political candidates; and it hampers grassroots political activity. These problems are not the result of a poorly designed regulatory structure, but rather the inevitable result of a regulatory structure built on faulty assumptions. ${ }^{207}$

\section{SOME COMMENTS ON Public Funding}

The criticisms leveled against campaign finance reform efforts in Part IV assumed a system of private campaign funding. However, the ultimate goal of a significant part of the reform movement is to entirely replace private funding of campaigns with public financing. ${ }^{208}$ Public financing would, it is suggested, remove the allegedly corrupting influence of money, place candidates for office on equal footing, and relieve candidates of the need for constant fund-raising. In fact, public financing is unlikely to achieve these goals, does not eliminate the undemocratic effects described in the preceding part, and raises significant problems in its own right. ${ }^{209}$

litigation was McIntyre exonerated by the Supreme Court. Before the Supreme Court, the State had argued that the Court's failure to uphold such regulation would make Buckley unenforceable. See Respondent's Brief at 20, McIntyre, 115 S. Ct. 1511 (No. 93-986).

206. Edward Zuckerman, Speechless in D.C., POL. FIN. \& LobBY REP., Nov. 9, 1994, at 1, 2. The regulation in question was struck down by the D.C. Circuit approximately one year after the 1994 elections. See Chamber of Commerce v. FEC, No. 94-5339, 1995 U.S. App. LEXIS 31925 (D.C. Cir. Nov. 14, 1995).

207. See supra Part III.

208. See, e.g., Raskin \& Bonifaz, supra note 52, at 1174-89 (arguing that Constitution requires public financing of campaigns).

209. The public generally opposes public financing. A December, $1990 \mathrm{NBC}$ News/Wall Street Journal poll found public funding opposed by $55 \%$ to $38 \%$. SORAUF, supra note 1 , at 145 . A January, $1990 A B C$ 
Most public-financing proposals are tied to limitations on the expenditure of private funds. ${ }^{210}$ Although the Supreme Court has held that Congress may not directly limit spending by candidates, ${ }^{211}$ Congress may link the receipt of public funds to voluntary spending limits. ${ }^{212}$ By operating as a spending cap, however, public funding would, like other campaign finance reforms, favor incumbents against challengers ${ }^{213}$ by further adding to incumbent advantages. ${ }^{214}$ Moreover, this problem might be exacerbated because incumbents would have incentives to set spending limits at levels that work in their favor. ${ }^{215}$

Some political scientists have responded to this argument by suggesting that public financing should not serve as a cap on expenditures, but rather as

News/Washington Post poll found $31 \%$ opposed, $20 \%$ in favor, and $49 \%$ undecided. Id. at 146. Some polls have shown more favorable responses to public financing. For example, a 1990 Greenberg-Lake/The Analysis Group poll found 58\% in favor and $33 \%$ opposed. Id. at 145 . However, that survey also showed that $60 \%$ of voters were against public financing when told that it would result in taxpayers paying for negative advertising. Id.; see also Russ Hemphill, Public Rejects Paying for Campaigns: Poll Finds Little Support for Higher Taxes, PHOENIX GAZETTE, Sept. 22, 1993, at B3 (providing results of poll in which more than $75 \%$ of Phoenix voters opposed public financing of city council campaigns). The public has also refused to support public financing at the ballot box or through tax returns. Voters have overwhelmingly defeated public-financing referenda in California, Elmer Enstrom Jr., Subsidizing Candidates: Californians Could Pay Despite Voter Opposition, SAN DIEGo UNION-TRIB., Nov. 4, 1993, available at 1993 WL 11764091 , and Phoenix, Arizona, Phoenix Election Post-Mortem: An Anti-Crime Mandate, ARIZ. REPUBLiC, Oct. 7,1993 , at B8. Only $14.2 \%$ of Americans voluntarily contributed to the presidential campaign fund through check-offs on their 1994 tax returns. Tom Herman, Tax Report, WALL ST. J., June 21, 1995, at Al. Minnesota's state check-off system also has participation rates below $20 \%$. SoRAUF, supra note 1 , at 143.

Of course, the lack of public support is not an insurmountable barrier: Presumably a well-organized campaign (perhaps financed by large private contributions) could convince a majority of the public that election financing is a good use of tax dollars.

There are also numerous administrative problems related to public-financing schemes, including: the allocation of funds to third parties and independents, Buckley v. Valeo, 424 U.S. 1, 293 (1976) (Rehnquist, J., dissenting); whether to allocate funds on a matching formula, Schotland, supra note 17, at 458-59; setting workable spending levels for races in vastly differing districts, $i d$. at 456; enforcement, $i d$. at 460; and cost. Although these difficulties should not be dismissed quickly, they can probably be addressed in a reasonable, if not wholly satisfactory, manner (at least if implementing public funding is the primary goal). My focus here is on more normative difficulties.

210. See, e.g., Lowenstein, supra note 3, at 354-59; Nicholson, supra note 3, at 475-78; Wertheimer \& Manes, supra note 3, at 1149-54.

211. Buckley, 424 U.S. at 54-59.

212. Id. at 85-109. However, the penalties for failing to accept "voluntary" limits may not be so steep as to amount to de facto compulsion under the Court's "unconstitutional conditions" doctrine. See, e.g., Kathleen M. Sullivan, Unconstitutional Conditions, 102 HARV. L. REv. 1413, 1415 (1989) ("The doctrine of unconstitutional conditions holds that government may not grant a benefit on the condition that the beneficiary surrender a constitutional right, even if the government may withhold that benefit altogether."). President Clinton's 1993 campaign finance proposal may have crossed the line into unconstitutional conditions by including significant penalties for candidates who did not accept the voluntary limits, coupled with substantial added subsidies to their competitors. See ADVANTAGE INCUMBENTS, supra note 155, at 11.

213. See supra Section IV.A.

214. Professor Nicholson, at least, is willing to live with this result. See Nicholson, supra note 3, at 475.

215. See Sunstein, supra note 14, at 1402-03; see also Lowenstein, supra note 3, at 335 (noting that President Bush's 1989 campaign finance proposals would have favored Republicans and that those proposing reform in Congress generally design plans benefiting their own party). 
a floor. ${ }^{216}$ Under this theory, public financing would be used to assure that each major-party candidate had sufficient funds to run a minimally competitive race for office. Candidates could then supplement their public funds with unlimited private spending. Such an approach would avoid the disadvantages of spending and contribution limits and would, perhaps, help to make more campaigns competitive. However, it would leave unaddressed the central concerns of the reformers-the supposedly corrupting influence of private money on the political system and alleged political inequality-thereby undercutting much of the basic rationale for public funding. Public funding could still address these issues indirectly, by making the "floor" so high that spending private funds above the floor would yield only very marginal, or even zero, returns. But leaving aside the public expense that such a high floor would entail, making private spending meaningless would have many of the same undemocratic consequences as would contribution limits in a system of private financing. It would remove incentives for legislative monitoring by groups and individuals, ${ }^{217}$ it would drive one source of political power from the field, thereby increasing the influence of elites who draw power from other sources; ${ }^{218}$ and it might foster the more traditional corruption of outright bribery. ${ }^{219}$ Thus, besides creating difficult administrative hurdles, public funding could be expected to produce many of the same problems that reform efforts produce in the context of private funding.

\section{CONCLUSION: THE UTILITARIAN FIRST AMENDMENT}

Professor Schotland has argued that the great dilemma of campaign finance is how to maintain political equality in a society that accepts economic inequality. ${ }^{220}$ This theme is a recurrent one in the literature of campaign finance reform $^{221}$-it focuses on the perceived tension between the First Amendment's role in protecting individual liberty and its role in promoting self-government and societal benefits. ${ }^{222}$ This part will suggest that this formulation is incorrect, and that the conflict perceived by reform advocates does not, in fact, exist. Properly understood, the First Amendment serves both the libertarian goals of some reform critics and the egalitarian goals of reformers.

216. See Joel L. Fleishman \& Pope McCorkle, Level-Up Rather Than Level-Down: Towards a New Theory of Campaign Finance Reform, 1 J.L. \& Pol. 211, 230-34 (1984); Sabato, supra note 107, at 169.

217. See supra notes $168-69$ and accompanying text.

218. See supra Section IV.C.

219. See supra notes $170-71$ and accompanying text.

220. See Schotland, supra note 17 , at 435 .

221. See, e.g., Edwin B. Firmage \& Kay Christensen, Speech and Campaign Reform: Congress, the Courts and Community, 14 GA. L. REv. 195, 218 (1980); Shockley, supra note 140, at 691-99; Strauss, supra note 92, at 1383-85; Sunstein, supra note 14, at 1413.

222. See, e.g., Shapiro, supra note 135 , at 393-94. 
Early thought on the First Amendment tended to view it in terms of an individual liberty interest. Thomas Jefferson, for example, saw freedom of opinion as a "natural right" of the individual. ${ }^{223}$ Another view, which was dominant by the latter part of the nineteenth century, was that the First Amendment, though based on individual liberty interests, served merely to codify common law rights inherited by the American colonists from their English ancestors. ${ }^{224}$ Neither Jefferson's view, nor the common law view, provided an absolute liberty in speech. Jefferson allowed for limitations on libelous speech. ${ }^{225}$ The common law allowed for the speaker to be punished for libelous, obscene, or blasphemous speech, ${ }^{226}$ but clearly prohibited prior restraints. ${ }^{227}$ Beginning around 1870, a third strain of First Amendment jurisprudence emerged. This was a judicial laissez-faire ideology that offered greater protection to speech based on the lack of legitimate authority for state interference in private speech. ${ }^{228}$

Progressive reformers at the turn of the century were generally pleased by the notion of greater speech protection offered by this third strain of thought, but unhappy with basing that support on an individual liberty interest that might also be used to strike down economic regulation. ${ }^{229}$ Thus, Progressive thinkers began to develop a new rationale for broad protection of free speech: Speech was not to be protected as a liberty interest, but as a prerequisite to a properly functioning democracy. ${ }^{230}$ Particularly influential in this effort was Zechariah Chafee. Chafee was not unmindful of the liberty interest in speech, but argued that "it is useless to define free speech by talk about rights.",23i "The true meaning of freedom of speech," he wrote, "is the discovery and spread of truth on subjects of general concern." 232 In the Chafee formulation, soon promoted on the Supreme Court by Oliver Wendell Holmes, ${ }^{233}$ the right to free speech became a utilitarian instrument for administering government, rather than a natural right or a right inherited from the common law that would be, in Jefferson's words, "useless to surrender to the government."234

Chafee's de-emphasis of the individual liberty interest in speech did not lead initially to a lower threshold of constitutional protection, but instead to

223. DAVID N. MAYER, The Constitutional. Thought of Thomas JeFFERSON 159 (1994).

224. G. Edward White, Justice Holmes and the Modernization of Free Speech Jurisprudence: The Human Dimension, 80 CAL. L. REV. 391,398 (1992).

225. MAYER, supra note 223 , at 171 .

226. White, supra note 224 , at 398 .

227. Id. Jefferson's views, which are typical of radical Whig thought at the time, may have shifted to a more absolutist position after passage of the Alien and Sedition Acts. MAYER, supra note 223, at 173-74.

228. White, supra note 224 , at $403-06$.

229. Id. at 406 .

230. Id. at 407 .

231. Zechariah Chafee, Jr., Freedom of Speech in War Time, 32 HaRv. L. REV. 932, 957 (1919).

232. Id. at 956 .

233. See Abrams v. United States, 250 U.S. 616, 630 (1919) (Holmes, J., dissenting).

234. MAYER, supra note 223, at 155 (quoting Jefferson). 
arguably greater protection than speech had ever before enjoyed, at least so long as that speech contained some political element. By mid-century, the great First Amendment theorist, Alexander Meiklejohn, argued that, as applied to political speech, the First Amendment was all but absolute. ${ }^{235}$ Nevertheless, the "self-governance" theory of the First Amendment articulated by Chafee and Meiklejohn eroded the traditional individual liberty justification for protecting free speech. Without this underpinning, when Meiklejohn's absolutist utilitarian view was challenged, ${ }^{236}$ intrusions on free speech rights became harder to resist-particularly when those intrusions were effected in the name of furthering self-governance. By 1961, even Meiklejohn would write, "A citizen may be told when and where and in what manner he may or may not speak, write, assemble, and so on."237 The Supreme Court, too, seemed to move in this direction, approvingly quoting Meiklejohn in a 1973 opinion for the proposition that the First Amendment is intended to ensure not that speech is unrestricted but rather that all voices are heard. ${ }^{238}$

In 1975, the D.C. Circuit upheld FECA in its entirety on this basic rationale. ${ }^{239}$ According to the opinion written by Judge Tamm in Buckley, the equality principle inherent in the First Amendment justified the regulation. ${ }^{240}$ The Supreme Court reversed much of the circuit court's opinion and struck down many parts of the Act. ${ }^{241}$ In doing so, the Court rejected the pro-FECA equality argument, ${ }^{242}$ and appeared to return to the old "individual liberty interest" mode of analysis. ${ }^{243}$ The debate that has taken place since has often been a battle between these conflicting views. ${ }^{244}$ Opponents of reform have argued from an individual rights-based point of view. ${ }^{245}$ Reformers have argued that the First Amendment is properly understood as a utilitarian measure. They claim that it ought not to be interpreted to restrain most campaign finance regulations ${ }^{246}$ and that it could in some cases even be

235. Alexander Meiklejohn, Free Speech and Its Relation to Self-Government 27, 91 (1948). Meiklejohn did seem to leave open the question, however, as to whether or not the First Amendment protected lobbyists. See id. at 99. Meiklejohn's absolutist position went beyond anything that Chafee had envisioned. See Zechariah Chafee, Jr., Book Review, 62 HARV. L. REV. 891,898 (1949).

236. See Chafee, supra note 235 , at $898-901$.

237. Alexander Meiklejohn, The First Amendment is an Absolute, 1961 SUP. CT. REV. 245, 257.

238. CBS, Inc. v. Democratic Nat'l Comm., 412 U.S. 94, 122 (1973).

239. Buckley v. Valeo, 519 F.2d 821 (D.C. Cir. 1975), aff'd in part and rev'd in part, 424 U.S. 1

(1976) (per curiam).

240. Id. at 897.

241. Buckley, 424 U.S. 1.

242. Id. at 15-17, 19-22, 25-26.

243. See Harold Leventhal, Courts and Political Thickets, 77 CoLUM. L. REV. 345, 360 (1977); Polsby, supra note 16 , at 17.

244. For examples of authors arguing that First Amendment values may require limits on the speech of some individuals, see, e.g., SUNSTEIN, supra note 49; Fiss, supra note 4, at 1405. The opposing, libertarian view is well represented by, among others, RALPH K. WINTER, JR. \& JOHN R. BOLTON, CAMPAIGN FinANCING AND POlitiCAL FREEDOM (1973); BeVier, supra note 15; Polsby, supra note 16.

245. See, e.g., BeVier, supra note 89 , at 1258 .

246. See, e.g.. Fiss, supra note 4, at 1425 ("[U]nless the Court allows, and sometimes even requires, the state to [restrict the speech of some elements of society], we as a people will never truly be free."); 
interpreted to require them ${ }^{247}$ as a means of promoting a principle of equality they consider inherent in our system of self-governance.

The end result of a debate structured in this manner is that the defense of the right to unabridged speech has been left largely to conservatives who have less concern over alleged inequalities. ${ }^{248}$ Martin Shapiro writes:

[A]lmost the entire first amendment literature produced by liberal academics in the past twenty years has been a literature of regulation, not freedom-a literature that balances away speech rights. ... Its basic strategy is to treat freedom of speech not as an end in itself, but an instrumental value $\ldots . .^{249}$

Professor Shapiro is clearly dismayed by this turn of events. ${ }^{250}$ But Shapiro's fears have not moved those who have made clear their desire to balance First Amendment rights away. For that reason, this Essay, while not conceding the individual liberty interpretation of the First Amendment, has attempted to address the reformist literature on its own, utilitarian terms. In doing so, it has argued that the reformist approach has been based on assumptions that are, at best, significantly overstated, and, at worst, wrong. Moreover, after twenty years of balancing speech rights away, liberal scholarship is in danger of losing the ability to see the First Amendment as anything but a libertarian barrier to equality that may, and indeed ought, to be balanced away or avoided with little thought. ${ }^{251}$ Even when the reform literature has expressed concern over the consequences of its proposals, it has done so with the certainty that the First Amendment must, nonetheless, give way. This is a serious error.

Twenty years of FECA and similar state laws have not only failed to deliver on reformist promises, ${ }^{252}$ but, as this Essay has argued, have themselves had undemocratic consequences for the electoral system. Further, the problems created by reform efforts cannot be explained away simply by pointing to the truncated nature of permissible reform after Buckley. Such

Leventhal, supra note 243, at 387 (arguing that because "[n]ew political structures and processes are needed for our dynamic society," courts should proceed cautiously in striking down reform measures); Shockley, supra note 140, at 697 (arguing that Supreme Court's Buckley decision "certainly goes against some of the basic ideas of the meaning of the First Amendment"); Strauss, supra note 92, at 1385 (arguing that if equality in voting is required, it "is difficult to see why" contributions cannot be limited to assure equality); Wright, supra note 4, at 609 ("Campaign spending reform is imperative to serve the purposes of freedom of expression.").

247. See, e.g., Foley, supra note 185 (arguing that Constitution requires that financial participation in politics be equalized through a system of subsidies and taxes); Raskin \& Bonifaz, supra note 52 (arguing that Constitution requires public funding of campaigns).

248. See, e.g.. Buckley, 424 U.S. at 235-55 (Burger, C.J., concurring in part \& dissenting in part); Polsby, supra note 16: Ralph K. Winter, Political Financing and the Constitution, 486 ANNALS AM. ACAD. POL. \& SoC. SCI. 34 (1986).

249. Shapiro, supra note 135, at 393.

250. See $i d$. at 394 (noting that such regulation raises "a very particular danger").

251. See Fiss, supra note 4, at 1425.

252. Burke, supra note 63, at 391 (discussing federal laws). 
problems would exist even if Buckley were overturned and the reformist legislative goals were realized. Efforts to drive money from the playing field of politics will entrench incumbents, make the system less responsive to popular opinion, concentrate power in the hands of select elites, and depress grassroots political activity.

Reformers, after years of citing First Amendment "values" as a justification for limits on speech rights, ${ }^{253}$ seem content to ignore the actual language of the First Amendment, which prohibits such abridgements of speech. In making this leap, they appear not to have considered the possibility that the First Amendment should itself be seen as a considered response to problems inherent in any democratic system of elections.

By assuring freedom of speech and of the press, the First Amendment allows for exposure of government corruption and improper favors and provides voters with information on sources of financial support. There is no shortage of newspaper articles reporting on candidate spending and campaign contributions, and candidates frequently make such information an issue in campaigns. By keeping the government out of the electoral arena, the First Amendment allows for a full interplay of political ideas and prohibits the type of incumbent self-dealing that has so vexed the reform movement. It allows challengers to raise the funds necessary for a successful campaign and keeps channels of political change open. By prohibiting excessive regulation of political speech and the political process, the First Amendment, properly interpreted, frees individuals wishing to engage in political discourse from the regulation that now restrains grassroots political activity. And because the First Amendment, properly applied to protect contributions and spending, makes no distinctions between the power bases of different political actors, it helps to keep any particular faction or interest from permanently gaining the upper hand. In each respect, it promotes true political equality.

What the First Amendment does not do is promise a neat and tidy system of elections. Campaign finance reformers, focused on the untidiness of the process, which they have labeled "corruption," have responded with an ever growing web of regulation. This has served only to distance Americans from politics and politicians and has thus led to a decline in the public's trust in government.

The problems of self-government in the twenty-first century are unlikely to be resolved by piling more regulations on top of a failed system of campaign finance regulation. Instead, we should recognize the flawed assumptions that have motivated campaign finance reform efforts and the undemocratic consequences that have resulted. Doing so may enable us to take more seriously the benefits of the system of campaign finance regulation that

253. See Fiss, supra note 4, at 1408-13; Shockley, supra note 140, at 691-99; Sunstein, supra note 14 , at 1413; Wright, supra note 4 , at $626-31$. 
the Founders wrote into the Bill of Rights-both as an end in itself and as an instrumental value to the goal of a functioning democracy. That system is a simple one. It begins: "Congress shall make no law . . .."254

254. U.S. CONST. amend. I. 
